\title{
Climatic controls on watershed reference evapotranspiration vary dramatically during the past 50 years in southern China
}

Mengsheng Qin ${ }^{1}, \mathrm{Lu} \mathrm{Hao}^{1}$, Lei Sun ${ }^{1}$, Yongqiang $\mathrm{Liu}^{2}$, and Ge Sun ${ }^{3}$

${ }^{1}$ Key Laboratory of Meteorological Disaster, Ministry of Education (KLME) / Joint International

Research Laboratory of Climate and Environment Change (ILCEC) / Collaborative Innovation Center on Forecast and Evaluation of Meteorological Disasters (CIC-FEMD) / Jiangsu Key Laboratory of Agricultural Meteorology, Nanjing University of Information Science \& Technology, Nanjing 210044, China

${ }^{2}$ Center for Forest Disturbance Science, Southern Research Station, USDA Forest Service, Athens, GA

${ }^{3}$ Eastern Forest Environmental Threat Assessment Center, Southern Research Station, USDA Forest

Service, Raleigh, NC 27606, USA

Correspondence to: Lu Hao (h﹎haolu@163.com); Ge Sun (gesun@fs.fed.us) 
Hydrol. Earth Syst. Sci. Discuss., doi:10.5194/hess-2017-241, 2017

Manuscript under review for journal Hydrol. Earth Syst. Sci.

Discussion started: 2 May 2017

(c) Author(s) 2017. CC-BY 3.0 License.

(c) (1)
Hydrology and

Earth System

Sciences

Discussions

\section{Abstract}

Reference evapotranspiration (ETo) is an important hydrometeorological term widely used in water resource management, hydrological modeling, and understanding and projecting the hydrological effects of future climate change and land use change. Identifying the individual climatic controls on ETo helps better understand the processes of global climatic change impacts on local water resources and also simplify modeling efforts to predict actual evapotranspiration. We conducted a case study on the Qinhuai River Basin (QRB), a watershed dominated by a humid subtropical climate and mixed land uses in southern China. Long term (1961-2012) daily meteorological data at six weather stations across the watershed were used to estimate ETo by the FAO-56 Penman-Monteith model. The seasonal and annual trends of ETo were examined using the Mann-Kendall nonparametric test. The individual contributions from each meteorological variable were quantified by a detrending method. The results showed that basin-wide annual ETo had a decreasing trend during 1961-1987 due to decreased wind speed (WS), solar radiation $\left(\mathrm{R}_{\mathrm{s}}\right.$ ), vapor pressure deficit (VPD), and increased relative humidity (RH). These variables had different magnitudes of contribution to the ETo trend in different seasons examined during 1961-1987. However, during 1988-2012, both seasonal and annual ETo showed an increasing trend, mainly due to increased VPD and decreased RH and, to lesser extent, to decreased absolute humidity $(\mathrm{AH})$ and a rising air temperature. We show that the key climatic controls on ETo have dramatically shifted as a result of global climate change during the past five decades. Now the 
Hydrol. Earth Syst. Sci. Discuss., doi:10.5194/hess-2017-241, 2017

Manuscript under review for journal Hydrol. Earth Syst. Sci.

Discussion started: 2 May 2017

(c) Author(s) 2017. CC-BY 3.0 License.

(c) (1)
Hydrology and

Earth System

Sciences

Discussions

atmospheric demand, instead of air temperature alone, is a major control on ETo. Thus, we conclude that accurately predicting current and future ETo and hydrological change under a changing climate must consider changes in VPD (i.e., air humidity and temperature) in the study region. Water resource management in the study basin must consider the increasing trend of ETo to meet the associated increasing water demand for irrigation agriculture and domestic water uses.

\section{Introduction}

In the past three decades, dramatic climate change and human activities have altered global hydrological cycles including the evapotranspiration (ET) processes (Xu et al., 2015; Zalewski, 2000), resulting in a series of environmental and socio-economic impacts (Roderick et al., 2002). Indeed, ET is a key component of water and energy balances, an important topic in modern ecohydrological, meteorological, agricultural, and ecological studies (Yang et al., 2012; Zhao et al., 2014). Reference ET (ETo) which is defined as the rate of ET over a hypothetical underlying surface with fixed parameters is an essential component in estimating actual ET (Liu et al., 2017), hydrological modeling, and projecting the impact of changing weather conditions on water supply (Allen et al., 1998; Liu et al., 2010). McMahon et al. (2013) provided summary of techniques to estimate reference ET and suggested that the FAO-56 Penman-Monteith model was widely adopted and preferred in humid regions. Quantifying the individual role of climatic factors in controlling ETo is important for understanding the influence of climatic change on hydrologic processes in terrestrial ecosystems (Fan and Thomas, 2012; Chen et al., 
Hydrol. Earth Syst. Sci. Discuss., doi:10.5194/hess-2017-241, 2017

Manuscript under review for journal Hydrol. Earth Syst. Sci.

Discussion started: 2 May 2017

(c) Author(s) 2017. CC-BY 3.0 License.

(c) (1)
Hydrology and

Earth System

Sciences

Discussions

2006). These investigations have remarkable theoretical and practical significance for understanding watershed hydrological cycle and effective use of farming water resources (Yang et al., 2014; Xu et al., 2015).

Worldwide, numerous studies have examined the trends of ETo in many different regions but with different findings. Significant decreasing trends of ETo have been found in several river basins such as the Platte River Basin in central Nebraska in the USA during 1893-2007 (Irmak et al., 2012), the Tons River Basin, central India during 1969-2008 (Darshana et al., 2013), and China's Qinghai-Tibetan plateau during 1971-2004 (Zhang et al., 2009) and Yunnan province during 1961-2004 (Fan et al., 2013). These studies showed that decreased ETo occurred in some regions despite the global temperature has increased by $0.13^{\circ} \mathrm{C}$ per decade in the last 50 years (IPCC, 2007).

The variable climatic controls on ETo have been examined under different climatic regimes. Jhajharia et al. (2012) found the decreased WS and declined net radiation overwhelmed the effect of increased air temperature, causing the decreased ETo in a humid region in northeast India during 1978-2002. In western Iran, the increasing trend of ETo was mainly caused by a significant increase in air temperature during 1966-2005 (Tabari et al., 2011a). No changes in ETo were found from 1964 to 1998 in Bet Dagan on Israel's central coastal plain because the effects of rising aerodynamic term were counterbalanced by the decreasing radiation term (Cohen et al., 2002).

In China, similar climate attribution studies have been conducted in different regions. Chen et al. 
Hydrol. Earth Syst. Sci. Discuss., doi:10.5194/hess-2017-241, 2017

Manuscript under review for journal Hydrol. Earth Syst. Sci.

Discussion started: 2 May 2017

(c) Author(s) 2017. CC-BY 3.0 License.

(c) (i)
Hydrology and

Earth System

Sciences

Discussions

(2011) proposed that the decrease in ETo in the Sichuan Basin of southwestern China was mainly due to

75 the decreased sunshine hours. Zhang et al. (2010) found the combined effects of decreased WS and sunshine hours offset the impact of increased air temperature, and then caused the decreased ETo in northeast China. Yang et al. (2014) proposed that increased maximum temperature was the main reason for the rise of ETo in Taohe River basin in northwest China during 1981-2010.

Our review of literatures suggests that (i) few studies have been carried out in the humid region of

southern China, (ii) both increasing and decreasing trends of ETo were detected in different regions of China and elsewhere, and (iii) not only air temperature affected changes of ETo but also other meteorological variables including wind speed (WS), solar radiation $\left(\mathrm{R}_{\mathrm{s}}\right)$, relative humidity $(\mathrm{RH})$, absolute humidity (AH), and vapor pressure deficit (VPD) affected ETo to different extent. Therefore, there is a need to study the long term trend of ETo and comprehensive influence of various climatic factors to ETo in humid regions of southern China.

The Qinhuai River Basin (QRB) used for this case study has a subtropical climate typical of the lower Yangtze River Delta region in China. The region is rapidly developing and has been facing more environmental challenges such as land subsidence, water pollution, flooding, and urban heat islands (UHIs) (Liu et al., 2013; Zhao et al., 2014; Zhou et al., 2014). The QRB includes several cities with a population over 8 million and water demand for drinking, irrigation and industry use has placed great pressure on water resources management in this "water rich" region. Our previous study (Hao et al., 
Hydrol. Earth Syst. Sci. Discuss., doi:10.5194/hess-2017-241, 2017

Manuscript under review for journal Hydrol. Earth Syst. Sci.

Discussion started: 2 May 2017

(c) Author(s) 2017. CC-BY 3.0 License.

(c) (i)
Hydrology and

Earth System

Sciences

Discussions

2015) suggests that rapid urbanization by converting paddy fields and water withdrawal for large-scale irrigation in this basin have dramatically altered the watershed hydrology through changes in ET and surface water. A further understanding of the climatic control on ETo could provide valuable information to understand watershed hydrological processes and projecting the impacts of climatic change and land use change on water resources in this basin.

Based on previous studies on ETo in the humid region, we proposed two hypotheses to guide our research: (i) ETo has significantly increased during the past 50 years in the QRB, (ii) In addition to the increased air temperature, other meteorological variables have influenced ETo variation to a different

degree. In this study, we aimed to: (i) calculate the ETo over the QRB for the period of 1961-2012 by the FAO-56 Penman-Monteith model, (ii) determine the trends of ETo and eight key meteorological variables with the Mann-Kendall (MK) nonparametric test, and (iii) identify the dominant climatic factors in changing ETo at seasonal and annual scales by a detrending method.

\section{Material and methods}

\subsection{Study area and databases}

The QRB is located in the southwest of Jiangsu province $\left(118^{\circ} 39^{\prime}-119^{\circ} 19^{\prime} \mathrm{E}, 31^{\circ} 34^{\prime}-32^{\circ} 10^{\prime} \mathrm{N}\right)$ (Fig.1) and possesses an area of $2617 \mathrm{~km}^{2}$ including Nanjing, Lishui, and Jurong cities. The land use is dominated by paddy rice field and dry cropland $(60 \%)$. The watershed has a flat topography with 
Hydrol. Earth Syst. Sci. Discuss., doi:10.5194/hess-2017-241, 2017

Manuscript under review for journal Hydrol. Earth Syst. Sci.

Discussion started: 2 May 2017

(c) Author(s) 2017. CC-BY 3.0 License.

(c) (i)
Hydrology and

Earth System

Sciences

Discussions

elevation ranging from 0 to $412 \mathrm{~m}$. The QRB has experienced a dramatic urbanization during the past

several decades (Du et al., 2012). By 2013, the built-up land has expanded to nearly $1 / 4$ of the whole

basin (Fig. 1). Irrigated paddy field covers nearly $35 \%$ of the basin representing the dominant land use.

Daily meteorological data from six standard weather stations in and around the QRB from 1961 to 2012 were provided by the China Meteorological Data Sharing Service System and Jiangsu Weather Bureau. Necessary variables to estimate ETo included WS ( $\left.\mathrm{m} \mathrm{s}^{-1}\right)$; RH (\%); sunshine duration $(\mathrm{n}, \mathrm{h})$; 115 daily mean temperature $\left(\mathrm{T}_{\text {mean }},{ }^{\circ} \mathrm{C}\right)$; daily maximum and minimum temperature $\left(\mathrm{T}_{\max }\right.$ and $\left.\mathrm{T}_{\min },{ }^{\circ} \mathrm{C}\right)$.

Data from Jiangning station was available before 2007. The QRB is dominated by paddy rice field and the rice growing season is between May and October when flood irrigation is needed (Hao et al., 2015). Accordingly, besides four seasons and the annual scale, we also examined the rice growing season as the sixth study period.

\subsection{FAO-56 Penman-Monteith model for estimating ETo}

The FAO Penman-Monteith (P-M) model has been widely used to estimate ETo and applicable to humid conditions (Allen et al., 1998; McMahon et al., 2013). This model can be expressed:

$\operatorname{ET}_{\mathrm{o}} \frac{0.408 \Delta\left(\mathrm{R}_{\mathrm{n}}-\mathrm{G}\right)+\gamma \frac{900}{\mathrm{~T}+273} \mathrm{U}_{2}\left(\mathrm{e}_{\mathrm{s}}-\mathrm{e}_{\mathrm{a}}\right)}{\Delta+\gamma\left(1+0.34 \mathrm{U}_{2}\right)}$

where $\Delta$ is the slope of the saturated vapor pressure curve $\left(\mathrm{kPa}{ }^{\circ} \mathrm{C}^{-1}\right), R_{n}$ the net radiation $\left(\mathrm{MJ} \mathrm{m}^{-2}\right.$ 125 day $^{-1}$ ), $G$ the soil heat flux density $\left(\mathrm{MJ} \mathrm{m}^{-2}\right.$ day $^{-1}$ ) (zero on the daily scale), $T$ the mean daily air 
Hydrol. Earth Syst. Sci. Discuss., doi:10.5194/hess-2017-241, 2017

Manuscript under review for journal Hydrol. Earth Syst. Sci.

Discussion started: 2 May 2017

(C) Author(s) 2017. CC-BY 3.0 License.

(c) (i)
Hydrology and

temperature $\left({ }^{\circ} \mathrm{C}\right), U_{2}$ the mean daily wind speed at $2 \mathrm{~m}$ height $\left(\mathrm{m} \mathrm{s}^{-1}\right), e_{s}$ the saturated vapor pressure $(\mathrm{kPa}), e_{a}$ the actual vapor pressure $(\mathrm{kPa}), e_{s}-e_{a}$ the Vapor pressure deficit $(\mathrm{kPa})$, and $\gamma$ the psychrometric constant $\left(\mathrm{kPa}^{\circ} \mathrm{C}^{-1}\right)$.

Key radiation part in $\mathrm{P}-\mathrm{M}$ model was estimated by following equations:

$\mathrm{R}_{\mathrm{n}}=\mathrm{R}_{\mathrm{ns}}-\mathrm{R}_{\mathrm{nl}}$

$\mathrm{R}_{\mathrm{ns}}=(1-\alpha) \mathrm{R}_{\mathrm{s}}$

$\mathrm{R}_{\mathrm{s}}=\left(a+\mathrm{b} \frac{\mathrm{n}}{\mathrm{N}}\right) \mathrm{R}_{\mathrm{a}}$

$\mathrm{R}_{\mathrm{nl}}=\sigma\left(\frac{\mathrm{T}_{\max , \mathrm{k}}^{4}+\mathrm{T}_{\min , \mathrm{k}}^{4}}{2}\right)\left(0.34-0.14 \sqrt{\mathrm{e}_{\mathrm{a}}}\right)\left(1.35 \frac{\mathrm{R}_{\mathrm{s}}}{\mathrm{R}_{\mathrm{so}}}-0.35\right)$

where $R_{n s}$ and $R_{n l}$ are the incoming net shortwave and outgoing net longwave radiation ( $\left.\mathrm{MJ} \mathrm{m}^{-2} \mathrm{~d}^{-1}\right), \alpha$

the albedo fixed as $0.23, R_{s}$ the solar radiation $\left(\mathrm{MJ} \mathrm{m}^{-2} \mathrm{~d}^{-1}\right), n$ and $N$ the actual and maximum possible

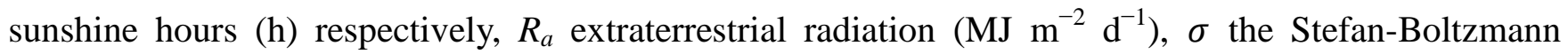
( $\left.4.903 \times 10^{-9} \mathrm{MJ} \mathrm{m}^{-2} \mathrm{~d}^{-1}\right), \mathrm{T}_{\text {max }, \mathrm{k}}$ and $\mathrm{T}_{\min , \mathrm{k}}$ the maximum and minimum absolute temperature within 24 hours $(\mathrm{K}), R_{s o}$ the clear sky solar radiation $\left(\mathrm{MJ} \mathrm{m}^{-2} \mathrm{~d}^{-1}\right), a$ and $b$ the empirical coefficients of 0.25 and 0.5 (Allen et al., 1998).

The VPD (kPa) is calculated as (Allen et al., 1998):

$\mathrm{VPD}=e_{s}-e_{a}$

where $e_{s}(\mathrm{kPa})$ can be calculated from $T_{\max }$ and $T_{\min }$ : 
Hydrol. Earth Syst. Sci. Discuss., doi:10.5194/hess-2017-241, 2017

Manuscript under review for journal Hydrol. Earth Syst. Sci.

Discussion started: 2 May 2017

(c) Author(s) 2017. CC-BY 3.0 License.

(c) (i)
Hydrology and

$\mathrm{e}_{\mathrm{s}}=\frac{\mathrm{e}^{0}\left(\mathrm{~T}_{\max }\right)+\mathrm{e}^{0}\left(\mathrm{~T}_{\min }\right)}{2}$

$\mathrm{e}^{0}\left(\mathrm{~T}_{\max }\right)=0.6108 \exp \left[\frac{17.27 \mathrm{~T}_{\max }}{\mathrm{T}_{\max }+273.3}\right]$

$145 \mathrm{e}^{0}\left(\mathrm{~T}_{\min }\right)=0.6108 \exp \left[\frac{17.27 \mathrm{~T}_{\min }}{\mathrm{T}_{\min }+273.3}\right]$

Finally, we computed $e_{a}(\mathrm{kPa})$ with the $e_{s}$ and measured daily mean relative humidity (RH):

$\mathrm{e}_{\mathrm{a}}=\mathrm{e}_{\mathrm{s}} * R H$

Absolute humidity $\left(\mathrm{AH}, \mathrm{g} \mathrm{m}^{-3}\right)$ was calculated with $e_{a}$ :

$\mathrm{AH}=\mathrm{c} \frac{\mathrm{e}_{\mathrm{a}}}{\mathrm{T}}$

150 where $c$ is a constant with 217 (Xie et al., 2014).

\subsection{Mann-Kendall (MK) test}

The nonparametric MK test (Mann 1945; Kendall 1975) was applied to analyze the trends of seasonal and annual ETo in many hydrological studies (Li et al., 2013; Liu et al., 2010; Fan et al., 2016). The statistic $S$ is calculated as

$155 S=\sum_{k=1}^{n-1} \sum_{j=k+1}^{n} \operatorname{sgn}\left(X_{j}-X_{k}\right)$

where $X_{j}$ represents the sequential data values, $n$ is the number of the dataset, and

$\operatorname{sgn}\left(X_{j}-X_{k}\right)=\left\{\begin{array}{r}1 \text { if } X_{j}-X_{k}>0 \\ 0 \text { if } X_{j}-X_{k}=0 \\ -1 \text { if } X_{j}-X_{k}<0\end{array}\right.$

When $n$ is greater than $10, S$ is approximately normally distributed with $\mathrm{E}(\mathrm{S})=0$ and variance of 
Hydrol. Earth Syst. Sci. Discuss., doi:10.5194/hess-2017-241, 2017

Manuscript under review for journal Hydrol. Earth Syst. Sci.

Discussion started: 2 May 2017

statistic $\mathrm{S}$ can be calculated by:

$\operatorname{Var}(S)=\frac{1}{18}\left[n(n-1)(2 n+5)-\sum_{w=1}^{v} t_{p}\left(t_{w}-1\right)\left(2 t_{w}+5\right)\right]$

where $v$ is the number of tied groups and $t_{\mathrm{w}}$ is number of data values in $w$ th group.

The standard test statistic $(Z)$ is:

$Z=\left\{\begin{array}{c}\frac{s-1}{\sqrt{\operatorname{Var}(s)}} \text { if } s>0 \\ 0 \quad \text { if } s=0 \\ \frac{s+1}{\sqrt{\operatorname{Var}(s)}} \text { if } s<0\end{array}\right.$

The null hypothesis $H O$ is rejected when $|\mathrm{Z}|>\mathrm{Z}_{1-\alpha / 2}$, where $\mathrm{Z}_{1-\alpha / 2}$ is the standard normal deviates.

\subsection{Theil-Sen's estimator}

Theil-Sen's estimator method was used to estimate magnitudes of ETo trends (Sen 1968; Hirsh 1982)

$\beta=\operatorname{Median}\left(\frac{X_{j}-X_{k}}{j-k}\right), 1<k<j<n$

where $\beta$ is the estimated magnitude of slopes of ETo trends. $\beta>0$ represents an increasing trend; $\beta<0$ represents a decreasing trend.

\subsection{Detrending method}

Previous studies (Xu et al., 2006; Liu et al., 2010; Li et al., 2013; Huo et al., 2013) provided a simple and effective detrending method to quantify the impacts of changing meteorological variables on ETo.

This method comprises of three steps: (i) removing the variation trend in different meteorological 
Hydrol. Earth Syst. Sci. Discuss., doi:10.5194/hess-2017-241, 2017

Manuscript under review for journal Hydrol. Earth Syst. Sci.

Discussion started: 2 May 2017

(c) Author(s) 2017. CC-BY 3.0 License.

(c) (i)
Hydrology and

Earth System

Sciences

Discussions

variables to make them as stationary dataset, (ii) recalculating ETo with one detrended variable while

175 keeping the other variables unchanged, and (iii) comparing the recalculated ETo with original ETo. The contribution of changes in climatic factors to changes in ETo could be quantified by an evaluating indicator $R$ :

$\mathrm{R}=\sum_{\mathrm{i}=1}^{\mathrm{n}} \frac{\left(\mathrm{ET}_{\mathrm{o}}^{\mathrm{o}}-\mathrm{ET}_{\mathrm{O}}^{\mathrm{R}}\right)}{\mathrm{ET}_{\mathrm{o}}^{\mathrm{o}}{ }_{\mathrm{i}}}$

where $\mathrm{ET}_{\mathrm{o}}^{\mathrm{o}}$ and $\mathrm{ET}_{\mathrm{o}}^{\mathrm{R}}$ are original and recalculated ETo respectively, n characterize the length of the data

set. $R>0$ denotes the change of this climatic factor has positive effects to the changes in ETo; $R<0$

denotes the change of this climatic factor has negative effects; and $R=0$ denotes the change of this climatic factor lead to little impact on changes of ETo. The larger value of $|R|$ denotes that change of this climatic factor has greater impact on the change of ETo (Li et al., 2013).

\section{Results}

\subsection{Climatic characteristics and trends}

Meteorological data from six standard weather stations over QRB were used to calculate watershed-wide mean values (Fig. 2). The multi-year daily mean temperature was $15.6^{\circ} \mathrm{C}$ and showed a significantly increasing trend $(p<0.05)$ since 1987 (Table 2). Mean annual precipitation was more than $1000 \mathrm{~mm}, 70 \%$ of which occurred in the growing season (Fig. 2c). Climate in four seasons is 
Hydrol. Earth Syst. Sci. Discuss., doi:10.5194/hess-2017-241, 2017

Manuscript under review for journal Hydrol. Earth Syst. Sci.

Discussion started: 2 May 2017

(c) Author(s) 2017. CC-BY 3.0 License.

(c) (1)
Hydrology and

Earth System

Sciences

Discussions

characterized by: (i) $\mathrm{T}_{\max }$ and $\mathrm{T}_{\min }$ reached peaks in summer (Fig. 2d), (ii) WS in QRB peaked in spring and declined to a nadir in autumn (Fig. 2a), which was similar to Geng et al. (2013), (iii) maximum $\mathbf{R}_{\mathrm{s}}$ occurred in summer (Fig. 2a), mainly caused by the longest sunshine duration, (iv) summer RH, AH and VPD were all higher than those in other seasons (Fig. 2b, c), and (v) $P$ peaked in summer (Fig. 2c) mainly caused by the Asian monsoons (Liang et al., 2010).

Overall, annual ETo in QRB firstly decreased during 1961-1987, then increased during 1988-2012.

The mutation point was discovered in 1987 (Table 3 and Fig. 3), which was closely related to abrupt changes in key meteorological variables that affected ETo trends (Fan et al., 2016). Therefore, we tested temporal trends for eight meteorological variables in 1961-1987 and 1988-2012 respectively (Table 1).

Spatially averaged WS showed significantly decreasing trends during 1961-1987 across all six seasons, while AH had insignificant changing trends across all seasons. The other six meteorological variables exhibited significantly changing trends across just a few seasons during 1961-1987 (Table 1). $\mathrm{R}_{\mathrm{s}}$ in QRB have decreased significantly in summer $(p<0.05)$ and the whole year $(p<0.05)$. Slops of decreased WS ranged from -0.034 to $-0.014 \mathrm{~m} \mathrm{~s}^{-1} \mathrm{yr}^{-1}$. We also found the slopes of decreased WS in spring, autumn and winter were all more than twice that in summer (Table 1), which indicated that the 205 effects of changes in summer WS might have the minimum contribution to changes of ETo over 1961-1987. In summer, RH has a significantly $(p<0.05)$ increasing trend with $0.11 \% \mathrm{yr}^{-1}$ and VPD has a significantly $(p<0.01)$ decreasing trend with $-0.005 \mathrm{kPa}^{-1}$ over QRB. For air temperature 
Hydrol. Earth Syst. Sci. Discuss., doi:10.5194/hess-2017-241, 2017

Manuscript under review for journal Hydrol. Earth Syst. Sci.

Discussion started: 2 May 2017

(c) Author(s) 2017. CC-BY 3.0 License.

(c) (1)
Hydrology and

Earth System

Sciences

Discussions

variables, $\mathrm{T}_{\text {mean }}$ exhibited significantly $(p<0.05)$ decreasing trend only in winter. However, $\mathrm{T}_{\max }$ and $\mathrm{T}_{\min }$ might cause negative effects to changes of ETo due to the significantly decreasing trends $(p<0.05)$

for summer during 1961-1987 (Table 1).

Different from 1961-1987, WS showed insignificant changing trends at all six seasons in 1988-2012 (Table 1). Conversely, RH and VPD have significantly changed at all six seasons. The difference was that RH had decreasing trends ranged from $-0.52 \% \mathrm{yr}^{-1}$ to $-0.2 \% \mathrm{yr}^{-1}$ and VPD had increasing trends

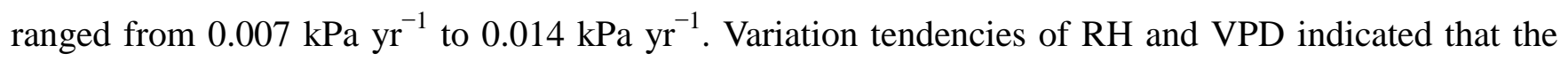
215 environment in QRB was becoming drier in the past decades, which contributed to the increased ETo. Across vast majority of the seasons, $\mathrm{T}_{\text {mean }}, \mathrm{T}_{\max }$ and $\mathrm{T}_{\min }$ have significantly increased with various slopes during 1988-2012. The largest increasing rates of $\mathrm{T}_{\text {mean }}$ and $\mathrm{T}_{\max }$ were both in spring, while $\mathrm{T}_{\min }$ has the largest increasing rate in autumn. In the four seasons of the year, smallest increasing rates of $\mathrm{T}_{\text {mean }}, \mathrm{T}_{\max }$ and $\mathrm{T}_{\min }$ were all found in summer (Table 1).

\subsection{Trends of ETo during 1961-1987 and 1988-2012}

The MK test and linear regression both showed that the annual ETo over QRB has significantly decreased $(p<0.01)$ during 1961-1987, then significantly increased $(p<0.01)$ during 1988-2012

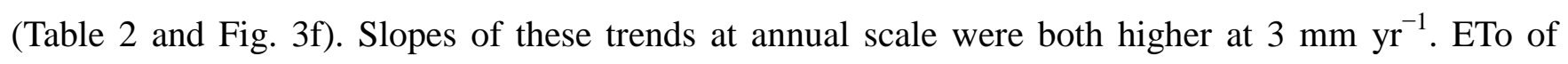
growing season occupied for nearly $70 \%$ of annual ETo in both two periods (Table 2). The growing season ETo exhibited significantly decreasing trend $(p<0.05)$ in $1961-1987$, while it was insignificant 
Hydrol. Earth Syst. Sci. Discuss., doi:10.5194/hess-2017-241, 2017

Manuscript under review for journal Hydrol. Earth Syst. Sci.

Discussion started: 2 May 2017

after 1987 (Table 2 and Fig. 3e). In four seasons, mean values of ETo during 1961-1987 were very close to those in 1988-2012 respectively (Table 2). Summer ETo in 1961-1987 had the highest decreasing slope and showed significantly decreasing trend $(p<0.01)$ (Table 2 and Fig. 3b). The highest increasing rate of ETo during 1988-2012 was found in spring and it was significant $(p<0.01)$ (Table 2 and Fig. 3a).

\subsection{Contributions of individual meteorological variables to the trends of ETo}

\subsubsection{Original and detrended meteorological variables}

The linear regression detrending method based on daily meteorological data was adopted to analyze the influence of changing meteorological variables on ETo. The seasonal and annual detrended results were

235 aggregated by the daily detrended results. Here we use Figure. 4 as an example to show obvious differences between original and detrended variables for annual scale.

In 1961-1987, only the original RH showed increasing trend which caused a lower detrended data (Fig. 4c). As negative trends were found for the other seven original variables, the drtended meteorological variables became larger. The biggest difference between original and detrended data was 240 observed in WS in 1961-1987 (Fig. 4b). In 1988-2012, the original $\mathrm{R}_{\mathrm{s}}$, RH and AH showed negative trends which caused the higher detrended results (Fig. 4a, c, d). Conversely, the other five original variables in 1988-2012 all showed positive trends which caused the lower detrended results (Fig. 4b, e, 
Hydrol. Earth Syst. Sci. Discuss., doi:10.5194/hess-2017-241, 2017

Manuscript under review for journal Hydrol. Earth Syst. Sci.

Discussion started: 2 May 2017

(c) Author(s) 2017. CC-BY 3.0 License.

(c) (1)
Hydrology and

Earth System

Sciences

Discussions

f). It is obvious that the differences between original RH, VPD and detrended RH, VPD were much larger than the other variables during 1988-2012. Based on the example of annual data (Fig. 4) and the trends of each original meteorological variable, we could distinguish the differences between each original and detrended meteorological variable on the seasonal scale.

\subsubsection{Contributions of meteorological variables to trends of ETo}

The annual original ETo and recalculated ETo with detrended variables were presented as an example to show the contrast of the two datasets (Fig. 5). During 1961-1987, only the recalculated ETo with detrended AH was lower than original ETo (Fig. 5c), while recalculated ETo values using other meteorological variables were all larger (Fig. 5a, c, e, g). Differences between annual original ETo and recalculated ETo with detrended $\mathrm{R}_{\mathrm{s}}$, WS, AH or VPD were obviously larger than differences between annual original ETo and recalculated ones with detrended RH, $\mathrm{T}_{\text {mean }}, \mathrm{T}_{\max }$ or $\mathrm{T}_{\min }$ (Fig. 5a, c, e, g). This phenomenon indicates that, in 1961-1987, the changes of first four variables had greater contributions to changes of ETo on the annual scale.

In 1988-2012, only the recalculated ETo with detrended $\mathrm{R}_{\mathrm{s}}$ was larger than the original one (Fig. 5b).

Obviously, the biggest differences were found between original ETo and the recalculated ETo with detrended RH or VPD (Fig. 5d, f). However, the smallest difference was observed between the original ETo and recalculated ETo with $\mathrm{T}_{\text {mean }}$. This indicates that changes of RH and VPD in 1988-2012 had the greatest influences on changes of ETo, but changes of $\mathrm{T}_{\text {mean }}$ had the smallest effects on the annual scale. 
Hydrol. Earth Syst. Sci. Discuss., doi:10.5194/hess-2017-241, 2017

Manuscript under review for journal Hydrol. Earth Syst. Sci.

Discussion started: 2 May 2017

(c) Author(s) 2017. CC-BY 3.0 License.

(c) (i)
Hydrology and

Earth System

Sciences

Discussions

The specific contributions of different variables to seasonal and annual ETo were further analyzed with the evaluating indicator $R$ (Fig. 6 and Fig. 7).

In 1961-1987, the effects of decreased $R_{s}$ and three temperature variables in spring were counterbalanced by the effects of changes in the other four variables, leading to little changes of ETo

(Fig. 6a). In summer and autumn months, only the decreased AH brought positive effects and then offset by the negative effects of changes in the other variables. For summer, decreased $R_{s}$, VPD and increased RH were the dominant factors for the decreased ETo (Fig. 6b). For autumn, the most likely causative factors became decreased WS and VPD (Fig. 6c). The negative effect of decreased WS was the main reason for the decreased ETo in winter during 1961-1987 (Fig. 6d). In the growing season, 270 decreased $\mathrm{R}_{\mathrm{s}}$, WS, VPD and increased RH were the main influencing factors in the decreased ETo (Fig. $6 e)$.

On the annual scale, positive effect of the decreased AH has been counterbalanced by the effects of decreased $R_{s}$, WS, VPD and increased RH. Decreased $T_{\max }$ was also an important factor for negative effects (Fig. 6f). This is consistent with the conclusion drawn from Figure 5. In general, decreased $R_{s}$, 275 VPD and increased RH mainly caused the decreased ETo in summer, while decreased WS was the main reason for decreased ETo in autumn and winter during 1961-1987. For spring, the effects of different meteorological variables offset each other and led to little changes of ETo. In growing season and the whole year, decreased ETo was greatly affected by more meteorological variables including $\mathrm{R}_{\mathrm{s}}$, WS, 
VPD, RH and $\mathrm{T}_{\max }$ (Fig. 6). offset the negative effect of changes in $\mathrm{R}_{\mathrm{s}}$, leading to the increased ETo (Fig. $7 \mathrm{~b}, \mathrm{c}$ ). In winter, it was obvious that changes of RH, AH and VPD had the greatest impacts and caused the positive trend of ETo

(Fig. 7d). The increased ETo in growing season and the whole year were mainly caused by the decreased RH and increased VPD (Fig. 7e, f). The decreased AH and increased air temperature were influencing factors to a lesser extent in growing season and the whole year. In general, increased VPD and decreased RH were the most influencing factors for positive trends in ETo for all seasons during 1988-2012.

\section{Discussion}

\subsection{Temporal trends of meteorological variables}

Generally speaking, $R_{\mathrm{S}}$ showed decreasing trends in the entire study period (Table 1). This is consistent with some previous studies (Liu et al., 2010; Yin et al., 2010; Li et al., 2013; Xu et al., 2015; Tabari et al., 2011a; Jhajharia et al., 2012). Irmak et al (2012) attributed this phenomenon to the increase in cloud cover and precipitation. The increase in atmospheric turbidity induced by the air pollution and dust 
Hydrol. Earth Syst. Sci. Discuss., doi:10.5194/hess-2017-241, 2017

Manuscript under review for journal Hydrol. Earth Syst. Sci.

Discussion started: 2 May 2017

(c) Author(s) 2017. CC-BY 3.0 License.

(c) (i)
Hydrology and o

storms could also reduce $\mathrm{R}_{\mathrm{s}}$ in China (Liu 2004; Zhang et al., 2004).

Significant decreased WS was observed both on seasonal and annual scales over QRB in the past three decades. A global decrease in terrestrial WS has also been observed (McVicar et al., 2012). In China, a decline of pressure gradient, climate warming and decreasing monsoon circulation commonly reduce atmospheric circulation and WS (Zhang et al., 2009; Zhang et al., 2014).

We found significantly decreased RH during 1988-2012 (Table 1). This is consistent with what was observed over land areas globally (Simmon et al., 2010). Simmon et al. (2010) found that the slope of increasing sea surface temperatures was smaller than that of increasing land temperatures, which would limited the evapotranspiration over oceans. Furthermore, the reduced evapotranspiration supply from oceans eventually led to the decreased RH over land in recent years (Simmon et al., 2010). On a regional scale, decreased RH was corresponding with the rapid warming (Wijngaarden et al., 2005; You et al., 2015) and RH was positively correlated with the change of precipitation (Jin et al., 2009). In addition to the impacts of changing meteorological variables, population increase and more frequent human activities (such as drainage system construction, expanded cement surface) contributed to the decreased air humidity in city (Wypych, 2009). During our study period, AH presented a negative trend over QRB (Table 1), which was similar to the situation in Guizhou province of southwest China (Han et al., 2016). However, Xie et al (2014) observed an increasing AH during 1951-2002 in the flatland of Haihe River basin in northern China. Moreover, Jiang et al (2015) observed two change points in the 
Hydrol. Earth Syst. Sci. Discuss., doi:10.5194/hess-2017-241, 2017

Manuscript under review for journal Hydrol. Earth Syst. Sci.

Discussion started: 2 May 2017

variation tendency of AH during 1960-2011 in the northern and southern regions of Qinling Mountains.

It is unclear about the causes of AH variation. Further studies are needed to explain the decreased AH over QRB.

VPD has significantly increased from 1988 to 2012 in the QRB (Table 1), which has also been observed globally (Matsoukas et al., 2011). Matsoukas et al. (2011) suggested that the global warming was an important factor for increased VPD. On a regional scale, increased VPD was also observed in

Bet Dagan, Israel in summer and autumn months (Cohen et al., 2002) and at a few sites of northeast India on the annual scale (Jhajharia et al., 2012). In the Platte River basin, the increased VPD was correlated to the air temperature and precipitation to a great extent. In our study basin, the increase in VPD was the most important controlling factor on the changes of ETo during 1988-2012 and attributed to these reasons: (i) the increase in saturated vapor pressure $\left(e_{s}\right)$ which was due to the warming trends and (ii) the decreased actual vapor pressure $\left(e_{a}\right)$ in $\mathrm{QRB}$.

This study found that increasing trend of air temperature were found in vast majority of seasons during 1988-2012 (Table 1). Warming trends are also reported in other regions in China such as the Yangtze River Delta (Cui et al., 2008), northern and southern regions of Qinling Mountains (Zhou et al., 2011), Jing River basin (Xu et al., 2015) and China as a whole (Han et al., 2013). Increasing trends of the three temperature variables had also been found in other parts of the world (Tabrai et al., 2011b; Jhajharia et al., 2012 Irmak et al., 2012; Darshana et al., 2013). Previous studies attributed the increased 
Hydrol. Earth Syst. Sci. Discuss., doi:10.5194/hess-2017-241, 2017

Manuscript under review for journal Hydrol. Earth Syst. Sci.

Discussion started: 2 May 2017

(c) Author(s) 2017. CC-BY 3.0 License.

(c) (i)
Hydrology and

Earth System

Sciences

Discussions

temperature variables to some reasons, for instance: global warming, increased greenhouse gases in the atmosphere (Soltani et al., 2008), expanded cloudage (Darshana et al., 2013), vast urbanization and industrialization (Tabari et al., 2011b; Roger and Pielke, 2005; Cui et al., 2008).

\subsection{Temporal trends and turning points of ETo during 1961-2012}

Most of the existing studies on the changing trend of ETo in China are conducted in water-shortage areas of northern China and the vast majority of these studies showed a continuous unidirectional change in ETo (Table 3). However, Xu et al. (2006) found ETo decreased significantly at annual scale during 1960-2000 at Yangtze River basin of the humid southern China. In contrast, in a short study (1971-2008), Yin et al. (2010) found an increased ETo trend in autumn over humid southeast coastal

China (Table 3). Abrupt change points have also been detected in a few studies. Zhang et al. (2013) presented an upward trend of ETo from 1960, changing to a declining trend in 1992 in China. ETo in Haihe River basin of northern China, on the basis of Zhao et al.'s (2015) study, showed a decreasing trend during 1960-1989 and then increased (Table 3). Similar to this basin, Fan's et al. (2016) found an abrupt change point of annual ETo existed in 1987 over the subtropical monsoon zone (south China). Huo et al. (2013) reported that the seasonal ETo decreased from 1955 to mid-1980s and then increased in the arid region of northwest China. However, the abrupt change points appeared in different years in these studies, which were closely related to the abrupt changes in key meteorological variables which affected ETo trends (Fan et al., 2016). Our study revealed a turning point (1987) in the variation 
Hydrol. Earth Syst. Sci. Discuss., doi:10.5194/hess-2017-241, 2017

Manuscript under review for journal Hydrol. Earth Syst. Sci.

Discussion started: 2 May 2017

tendency of ETo during 1961-2012.

\subsection{Contributions of meteorological variables to ETo trends}

Many studies found decreased trends of ETo in different basins under a warming climate (Table 3).

Different from these literatures, we found ETo follows the air temperature variation in this study (Table 1 and Table 2). Our analysis indicated that ETo was driven by not only air temperature but also other meteorological variables in both two periods. During 1961-1987, decreased WS was found to be the most influential factor causing negative effects on ETo in spring, autumn, winter and the whole year (Fig. 6a. c. d. f). This was consistent with some previous studies (Yin et al., 2010; Xu et al., 2015; Li et al., 2013; Chen et al., 2006; Jhajharia et al., 2012; Darshana et al., 2012). The most influential factor in the changes of ETo was decreased $R_{s}$ in summer and growing season (Fig. $6 b, e$ ), the same as studies in Yunnan province of southwestern China (Fan and Thomas, 2012), subtropical and tropical regions in China (Yin et al., 2010). Decreased VPD and increased RH were also important influencing factors contributing to the decreased ETo in summer and growing season during 1961-1987 (Fig. 6b, c). The increased RH was also found to contribute to the decreased ETo in Tibetan Plateau with the study period before 2000 (Chen et al., 2006). However, this situation was opposite to some previous studies which showed decreased RH (Li et al., 2013; Liu et al., 2010), mainly because of different study periods.

During 1988-2012, the positive trends of seasonal and annual ETo were dominated by the effects of decreased RH and increased VPD (Fig. 7). In another word, the gradually drying environment in QRB 
Hydrol. Earth Syst. Sci. Discuss., doi:10.5194/hess-2017-241, 2017

Manuscript under review for journal Hydrol. Earth Syst. Sci.

Discussion started: 2 May 2017

(c) Author(s) 2017. CC-BY 3.0 License.

(c) (1)
Hydrology and

Earth System

Sciences

Discussions

was the main reason for the increased ETo during 1988-2012. This was in line with situations in Yellow River basin (Liu et al., 2010), upper basin of Heihe River (Li et al., 2013), southern Taiwan (Yu et al., 2001) and west half of Iran (Tabari et al., 2011a). For the Yangtze River basin of southern China, Sensitivity coefficients of different climatic factors ranked as: $\mathrm{RH}>\mathrm{R}_{\mathrm{s}}>\mathrm{T}_{\text {mean }}>\mathrm{WS}$ (Gong et al., 2006). However, $\mathrm{Xu}$ et al. (2006) found decreased $\mathrm{R}_{\mathrm{s}}$ and WS contributed the most to the changes of ETo during 1960-2000. Fan et al. (2016) proposed that the reduction in sunshine hours was the main reason for the decreased ETo in subtropical monsoon zone of southern China during 1956-2015. It appears 375 that the climatic controls in our study watershed are different from these general long-term patterns identified by Xu et al. (2006) and Fan et al. (2016) for humid regions. The effects of changing VPD are more pronounced during the recent 30 years since the 1980s. In other studies during recent two or three decades (Zhang et al., 2013; Yang et al., 2014; Zhao et al., 2015) (Table 3), the rapidly increased air temperature was considered to be the main reason for increased ETo. These studies were also different from our results, because they focused the effects of air temperature with little attention to the effects of the changes in VPD. Our new analysis suggested that in addition to the increase in temperature, other factors such as increased VPD and decreased RH were the main causes for the observed increase in ETo in QRB. Our findings are consistent with Kingston et al. (2009) who suggested that in addition to air temperature, other meteorological variables were important in 385 estimating ETo. 


\subsection{Implication of increasing VPD and ETo for future agricultural water management}

Understanding water vapor distribution under climate change and an urbanizing environment is important to quantify altered hydrological processes. Most existing studies on water vapor focus on analyzing the surface relative humidity (Simmons et al., 2010; Vincent et al., 2007; Wijngaarden and Vincent, 2005). However, Novick et al. (2016) proposed that atmospheric demand for water was directly related to the vapor pressure deficit (VPD) which also affected the surface conductance to water vapor and ET. In our study, we found sharply increased VPD after 1987, which has caused the increased ETo over QRB. Combined with higher crop coefficients, the crop water demand in growing seasons would increase with the increase in ETo (Liu et al., 2010; Vu et al., 2005). In dry seasons (Spring and

Winter) when there is limited $P$, increased crop water demand aggravated water shortage and then led to serious adverse influence on food production (Fan et al., 2016). Wang et al. (2017) found technological progress such as improved irrigation systems, uses of greenhouses for growing crops and seed improvement could counterbalance the increasing crop water demand caused by the increase in ETo in China. However, in the Tibet plateau region and northeast China, the increased ETo overwhelmed the beneficial effect of technological progress, causing negative effects on crop growth (Lobell et al., 2011; Wang et al., 2017). Therefore, a drying condition and increasing ETo trend requires new management strategy for sustaining water resources in QRB. 


\section{Conclusions}

This long-term study (1961-2012) shows that ETo over Qinhuai River Basin has changed significantly

over the past 52 years: a decreasing trend during 1961-1987 and then an increasing trend during 1988-2012. Prior to 1987, decreased WS, $\mathrm{R}_{\mathrm{s}}$, VPD and increased relative humidity were responsible for the negative trends of ETo. The positive trends of ETo during 1988-2012 were mainly caused by effects of decreased relative humidity and increased VPD. The decreased absolute humidity and increased air temperature also contributed to the increased ETo to a lesser degree.

Paddy rice is the main crop that depends on water resources in southern China, especially in the lower Yangtze River Basin. Our study has important implications for watershed management in these paddy field-dominated regions, and similar humid regions, where actual water loss is mainly controlled by atmospheric demand. This study found an increase in ETo due to the increase in VPD in the recent decades, indicating that the water loss by evapotranspiration has been on the rise in the research 415 watershed. Rice paddies require regular irrigation in the growing season to sustain high productivity. Therefore, despite the humid climate, an increase in irrigation water demand in the rice planting area is expected in the future. Similarly, natural wetlands that are abundant in the study region may be affected as a result of hydrological change from atmospheric drying. Our study results also have an implication to watershed energy balance since water and energy are closely coupled. Urban heat island effects in the study basin may be also aggravated with an increase in air temperature and ETo and associated 
hydrological changes.

Future water management must also consider the recent shifts of climatic control on the hydrological cycles. Because atmospheric demand (VPD) is a major control on potential water loss over the study region, predicting hydrological change under a changing climate must consider both air humidity and 425 air temperature. Climate predictions from General Circulation Models (GCMs) must be assessed for their accuracy to simulate VPD in addition to air temperature and precipitation. In addition, potential ET algorithms that are often embedded in watershed hydrological models must include VPD as a major input variable to fully account for atmospheric water demand and actual ET.

Author Contribution: Mengsheng Qin, Lu Hao, and Ge Sun conceived and designed the research;

430 Mengsheng Qin performed the research; Mengsheng Qin and Lei Sun analyzed the data; Ge Sun,

Yongqiang Liu and Lu Hao supervised the research, and reviewed the paper. Mengsheng Qin prepared the manuscript with contributions from all co-authors.

Conflicts of Interest: The authors declare that they have no conflict of interest.

Acknowledgements. This research was funded by the National Natural Science Foundation of China 435 (Grant No. 41571026 and 71373130). We appreciate the anonymous reviewers for their constructive comments and suggestions. We thank China Meteorological Administration and Jiangsu Meteorological Bureau for sharing the climate data. Partial support was also received from the Southern Research Station, United States Department of Agriculture Forest Service. 
Hydrol. Earth Syst. Sci. Discuss., doi:10.5194/hess-2017-241, 2017

Manuscript under review for journal Hydrol. Earth Syst. Sci.

Discussion started: 2 May 2017

(c) Author(s) 2017. CC-BY 3.0 License.
Hydrology and

Earth System

Sciences

Discussions

\section{References}

Allen, R.G, Pereira, L.S, Raes, D, and Smith, M.: Crop evapotranspiration-guidelines for computing crop water requirements, FAO Irrigation and Drainage Paper 56, FAO. 1998.

Chen, C., Pang, Y. M., Pan, X. B., and Wang, C. Y.: Analysis on change of reference crop evapotranspiration and climaric influence fctors in Sichuan, Chinese Journal of Agrometeorological., 32, 35-40, doi: 10.3969/j.issn .1000 -6362. 2011. 01. 007, 2011.

Chen. S. B., Liu, Y. F., and Thomas, A.: Climatic change on the Tibetan Plateau: potential evapotranspiration trends from 1961-2000, Climatic Change., 76, 291-319, doi: 10.1007/s10584-006-9080-z, 2006.

Cohen, S., Ianetz, A., and Stanhill, G.: Evaporative climate changes at Bet Dagan, Israel, 1964-1998, Agr. Forest Meteorol., 111, 83-91, doi: 10.1016/S0168-1923(02)00016-3, 2002.

Cui, L. L., Shi, J., Yang, Y. M., Li, G. C., and Fan, W. Y.: Temperature change characteristics and its influence by urbanization in the Yangtze River Delta, Geog Raphical Research., 27:775-786, doi: 1000-0585(2008) 04-0775-12, 2008.

Darshana, Pandey, A., and Pandey, R. P.: Analysing trends in reference evapotranspiration and weather variables in the Tons River Basin in Central India, Stoch Environ Res Risk Assess., 27, 1407-1421, doi: 10.1007/s00477-012-0677-7, 2012.

Du, J., Qian, L., Rui, H., Zuo, T., Zheng, D., Xu, Y., and Xu, C. Y.: Assessing the effects of urbanization on annual runoff and flood events using an integrated hydrological modeling system for Qinhuai River basin, China, J. Hydrol., 464-465, 127-139, doi: 10.1016/j.jhydrol.2012.06.057, 2012.

Fan, J., Wu, L., Zhang, F., Xiang, Y., and Zheng, J.: Climate change effects on reference crop evapotranspiration across different climatic zones of China during 1956-2015, J. Hydrol., 542, 923-937, doi: 10.1016/j.jhydrol.2016.09.060, 2016.

Fan, Z. X. and Thomas, A.: Spatiotemporal variability of reference evapotranspiration and its contributing climatic factors in Yunnan Province, SW China, 1961-2004, Climatic Change., 116, 309-325, doi: 10.1007/s10584-012-0479-4, 2012.

Geng, X. Y. and Cao, G. C.: Changes in wind speed and its causes in Nanjing During the Period of 1960-2004, Science and Technology Information., 14, 122-125, doi: 10.16661/j.cnki.1672-3791.2013.14.181, 2013.

Gong, L. B., C. Y. Xu, D. L. Chen, S. Halldin, and Chen, Y. Q.: Sensitivity of the Penman-Monteith reference evapotranspiration to key climatic variables in Changjiang (Yangtze River) Basin, J. Hydrol., 329, 620-629, doi: 10.1016/j.jhydrol.2006.03.027, 2006.

Hao, L., Sun, G., Liu, Y., Wan, J., Qin, M., Qian, H., Liu, C., Zheng, J., John, R., Fan, P., and Chen, J.: Urbanization dramatically altered the water balances of a paddy field-dominated basin in southern China, Hydrol. Earth Syst. Sci., 19, 3319-3331, doi: 10.5194/hess-19-3319-2015, 2015.

Han, C. H., Hao, Z. X., and Zhang, J. Y.: Regionalization of temperature changes in China and characteristics of temperature in different regions during 1951-2010, Progress in Geograph., 32, 887-896., doi: 10.11820/dlkxjz.2013.06.005, 2013.

Han, H. Q., Cai, G. P., Wu, J., and Zhou, S.: Spatial and temporal variations of absolute humidity in Guizhou Province from 1960 to 2013, Journal of Sichuan Agricultural University., 34, 348-353, doi: 10. 16036/j. issn. 1000-2650. 2016. 03. 015, 2016.

Hirsh, R. M, Slack, J. R, and Smith, R. A.: Techniques of trend analysis for monthly waterquality data, Water Resour. Res., 
Hydrol. Earth Syst. Sci. Discuss., doi:10.5194/hess-2017-241, 2017

Hydrology and

Manuscript under review for journal Hydrol. Earth Syst. Sci.

Discussion started: 2 May 2017

Earth System

(c) Author(s) 2017. CC-BY 3.0 License.

Sciences

Discussions

(c) (i)

18, 107-121, doi: 10.1029/WR018i001p00107, 1982.

Huo, Z., Dai, X., Feng, S., Kang, S., and Huang, G.: Effect of climate change on reference evapotranspiration and aridity index in arid region of China, J. Hydrol., 492, 24-34, doi: 10.1016/j.jhydrol.2013.04.011, 2013.

Irmak, S., Kabenge, I., Skaggs, K. E., and Mutiibwa, D.: Trend and magnitude of changes in climate variables and reference evapotranspiration over 116-yr period in the Platte River Basin, central Nebraska-USA, J. Hydrol., 420-421, 228-244, doi: 10.1016/j.jhydrol.2011.12.006, 2012.

Jiang, C., Mu, X. M., Ma, W. Y., Yu, X. Y., Liu, X. F., Li, J. G., Liu, S. J., and Wang, F.: Spatial and temporal variation of absolute humidity and its relationship with potential evaporation in the northern and southern regions of Qinling Mountains, Acta Ecologica Sinica., 35, 378-388, doi: 10.5846 / stxb201401190145, 2015.

Jin, Y. H., Lian, S. H., Zhou, D. W., Xu, J. B., and Peng, C.: Study on change of relative humidity in semiarid region under global climate change, Journal of Northeast Normal University (Natural Science Edition), 41, 134-138, doi: 10.16163/ j.cnki.22-1123/n.2009.04.014, 2009.

Jhajharia, D., Dinpashoh, Y., Kahya, E., Singh, V. P., and Fakheri-Fard, A.: Trends in reference evapotranspiration in the humid region of northeast India, Hydrol. Process., 26, 421-435, doi: 10.1002/hyp.8140, 2012.

Kendall, M. G.: Rank correlation methods, Griffin, London, UK, 1975.

Kingston, D. G., Todd, M. C., Taylor, R. G., Thompson, J. R., and Arnell, N. W.: Uncertainty in the estimation of potential evapotranspiration under climate change, Geophys. Res. Lett., 36, 1437-1454, doi:10.1029/2009GL040267, 2009.

Liang, L.Q., Li, L.J., and Liu, Q.:Temporal variation of reference evapotranspiration during 1961-2005 in the Taoer River basin of Northeast China. Agr. Forest Meteorol., 150, 298-306, doi: 10.1016/j.agrformet.2009.11.014, 2010

Liu, B.: A spatial analysis of pan evaporation trends in China, 1955-2000, J. Geophys. Res., 109, 1255-1263, doi: 10.1029/2004jd004511, 2004.

Liu, C., Sun, G., McNulty, S. G., Noormets, A., and Fang, Y.: Environmental controls on seasonal ecosy stem evapotranspiration/potential evapotranspiration ratio as determined by the global eddy flux measurements, Hydrol. Earth Syst. Sci., 21, 311-322, doi: 10.5194/hess-21-311-2017, 2017.

Liu, Q., Yang, Z., Cui, B., and Sun, T.: The temporal trends of reference evapotranspiration and its sensitivity to key meteorological variables in the Yellow River Basin, China, Hydrol. Process., 24, 2171-2181, doi: 10.1002/hyp.7649, 5002010 .

Liu, Y., Zhou, Y., Ju, W., Chen, J., Wang, S., He, H., Wang, H., Guan, D., Zhao, F., Li, Y., and Hao, Y.:Changes of evapotranspiration and water yield in China's terrestrial ecosystems during the period from 2000 to 2010 , Hydrol. Earth Syst. Sci. Discuss., 10, 5397-5456, 10.5194/hessd-10-5397-2013, 2013.

Li, Z., Li, Z., Xu, Z., and Zhou, X.: Temporal variations of reference evapotranspiration in Heihe River basin of China, Hydrol. Process., 44, 904-916, doi: 10.2166/nh.2012.125, 2013.

Lobell, D. B., Schlenker, W., and Costa-Roberts, J.: Climate trends and global crop production since 1980. Science., 333, 616-620, doi: 10.1126/science.1204531, 2011.

Mann, H.B.: Nonparametric tests against trend, Econom. J. Econom. Soc, 245-259, 1945.

Matsoukas, C., Benas, N., Hatzianastassiou, N., Pavlakis, K. G., Kanakidou, M., and Vardavas, I.: Potential evaporation trends over land between 1983-2008: driven by radiative fluxes or vapour-pressure deficit, Atmos Chem Phys., 11, 
Hydrol. Earth Syst. Sci. Discuss., doi:10.5194/hess-2017-241, 2017

Hydrology and

Manuscript under review for journal Hydrol. Earth Syst. Sci.

Discussion started: 2 May 2017

Earth System

(c) Author(s) 2017. CC-BY 3.0 License.

Sciences

Discussions

(c) (i)

7601-7616, doi: 10.5194/acp-11-7601-2011, 2011.

McVicar, T. R., Roderick, M. L., Donohue, R. J., Li, L. T., Van Niel, T. G., Thomas, A., Grieser, J., Jhajharia, D., Himri, Y., Mahowald, N. M., Mescherskaya, A. V., Kruger, A. C., Rehman, S., and Dinpashoh, Y.: Global review and synthesis of trends in observed terrestrial near-surface wind speeds: Implications for evaporation, J. Hydrol., 416-417, 182-205, doi: 10.1016/j.jhydrol.2011.10.024, 2012.

McMahon, T. A., Peel, M. C., Lowe, L., Srikanthan, R., and McVicar, T. R.: Estimating actual, potential, reference crop and pan evaporation using standard meteorological data: a pragmatic synthesis, Hydrol. Earth Syst. Sci., 17, 1331-1363, doi: 10.5194/hess-17-1331-2013, 2013.

Novick, K. A., Ficklin, D. L., Stoy, P. C., Williams, C. A., Bohrer, G., Oishi, A. C., Papuga, S. A., Blanken, P. D., Noormets,

A., Sulman, B. N., Scott, R. L., Wang, L., and Phillips, R. P.: The increasing importance of atmospheric demand for ecosystem water and carbon fluxes, Nature Climate Change., 6, 1023-1027, doi: 10.1038/nclimate3114, 2016.

Pielke, R. A.: Land use and climate change, Science, 310, 1625-1626, doi: 10.1126/science.1120529, 2005.

Roderick, M. L. and Farquhar, G. D.: The cause of decreased pan evaporation over the past 50 years, Science., 298, 1410-1411, doi: 10.1126/science.298.5597.1410, 2002.

Sen, P. K.: Estimates of the regression coefficient based on Kendall's tau, J. Am. Stat. Assoc., 63, 1379-1389, 1968.

Simmons, A. J., Willett, K. M., Jones, P. D., Thorne, P. W., and Dee, D. P.: Low-frequency variations in surface atmospheric humidity, temperature, and precipitation: Inferences from reanalyses and monthly gridded observational data sets, J.

Geophys. Res., 115, 1-21, doi: 10.1029/2009jd012442, 2010.

Solomon, S., Qin, D., Manning, M., Chen, Z., Marquis, M., Averyt, K., Tignor, M., and Miller, H, L (eds) Climate change 2007: the physical science basis. Contribution of working group I to the Forth Assessment Report of the Intergovernmental Panel on Climate Change. Cambridge University Press, Cambridge, pp 1-18. 2007.

Soltani, E. and Soltani, A.: Climatic change of Khorasan, North-East of Iran, during 1950-2004, Res. J. Environ. Sci., 2: 316-322, doi: 10.3923/rjes.2008.316.322, 2008.

Tabari, H., Marofi, S., Aeini, A., Talaee, P. H., and Mohammadi, K.: Trend analysis of reference evapotranspiration in the western half of Iran, Agr. Forest Meteorol., 151, 128-136, doi: 10.1016/j.agrformet.2010.09.009, 2011a.

Tabari, H. and Talaee, P. H.: Recent trends of mean maximum and minimum air temperatures in the western half of Iran, Meteorol. Atmos. Phys., 111: 121-131, doi: 10.1007/s00703-011-0125-0, $2011 \mathrm{~b}$.

Van Wijngaarden, W. A., and Vincent, L. A.: Examination of discontinuities in hourly surface relative humidity in Canada during 1953-2003, J. Geophys. Res., 110, 3093-3109, doi: 10.1029/2005jd005925, 2005.

Vincent, L. A., van Wijngaarden, W. A., and Hopkinson, R.: Surface temperature and humidity trends in Canada for 1953-2005, J. Climate., 20, 5100-5113, doi: 10.1175/jcli4293.1, 2007.

Vu, S. H., Watanabe, H., and Takagi, K.: Application of FAO-56 for evaluating evapotranspiration in simulation of pollutant runoff from paddy rice field in Japan, Agr. water manage., 76, 195-210, doi: 10.1016/j.agwat.2005.01.012, 2005.

Wang, Z. L., Xie, P. W., Lai, C. G., Chen, X. H., Wu, X. S., Zeng, Z. Y., and Li, J.: Spatiotemporal variability of reference evapotranspiration and contributing climatic factors in China during 1961-2013, J. Hydrol., 544, 97-108, doi: 10.1016/j.jhydrol.2016.11.021, 2017.

Wypych, A.: Twentieth century variability of surface humidity as the climate change indicator in Kraków (Southern Poland), 
Hydrol. Earth Syst. Sci. Discuss., doi:10.5194/hess-2017-241, 2017

Manuscript under review for journal Hydrol. Earth Syst. Sci.

Discussion started: 2 May 2017

(c) Author(s) 2017. CC-BY 3.0 License.

Theor. Appl. Climatol., 101, 475-482, doi: 10.1007/s00704-009-0221-y, 2009.

Xie, F. Y., Wang, X. Q., and Wang, Z. F.: Variation trend and zooming increase of absolute humidity in the flatland of the Haihe River basin, Climatic and Environmental Research., 19, 23-30, doi: 10.3878/j.issn.1006-9585. 2012.12112, 2014.

Xu, L., Shi, Z., Wang, Y., Zhang, S., Chu, X., Yu, P., Xiong, W., Zuo, H., and Wang, Y.: Spatiotemporal variation and driving forces of reference evapotranspiration in Jing River Basin, northwest China, Hydrol. Process., 29, 4846-4862, doi: 10.1002/hyp.10541, 2015.

Xu, C.Y., Gong, L., Jiang, T., Chen, D., and Singh, V. P.: Analysis of spatial distribution and temporal trend of reference evapotranspiration and pan evaporation in Changjiang (Yangtze River) catchment, J. Hydrol., 327, 81-93, doi: 10.1016/j.jhydrol.2005.11.029, 2006.

Yang, L. S., Li, C. B., Wang, S. B., and Yang, W. J.: Sensitive analysis of potential evapotranspiration to key climaticfactors in Taohe River Basin, Transactions of the Chinese Society of Agricultural Engineering., 30, 102-109, doi: 10.3969/j.issn.1002-6819.2014.11.013, 2014.

Yang, Y., Shang, S., and Jiang, L.: Remote sensing temporal and spatial patterns of evapotranspiration and the responses to water management in a large irrigation district of North China, Agr. Forest Meteorol., 164, 112-122, doi: 10.1016/j.agrformet.2012.05.011, 2012.

Yin, Y., Wu, S., and Dai, E.: Determining factors in potential evapotranspiration changes over China in the period 1971-2008, Chinese Science Bulletin., 55, 3329-3337, doi: 10.1007/s11434-010-3289-y, 2010.

565 You, Q. L., Min, J. Z., Lin, H. B., Pepin, N., Mika, S., and Kang, S. C.: Observed climatology and trend in relative humidity in the central and eastern Tibetan Plateau, J. Geophys. Res.Atmos., 120, 3610-3621, doi: 10.1002/2014JD023031, 2015.

Yu, P. S., Yang,T. C., and Chou, C. C.: Effects of climate change on evapotranspiration from paddy fields in southern Taiwan, Climatic Change., 54, 165-179, doi: 10.1023/A:1015764831165, 2001.

Zalewski, M.: Ecohydrology-the scientific background to use ecosystem properties as management tools toward sustainability of water resources, Eco. Eng., 16: 1-8, 10.1016/S0925-8574(00)00071-9, 2000.

Zhao, L., Lee, X., Smith, R. B., and Oleson, K.: Strong contributions of local background climate to urban heat islands, Nature., 511, 216-219, doi:10.1038/Nature13462, 2014.

Zhao, N., Zeng, X., and Sun, H.: Impact of global dimming on reference evapotranspiration in Hai River basin, China, Proceedings of the International Association of Hydrological Sciences, 368, 287-292, doi: 10.5194/piahs-368-287-2015, 2015.

Zhang, X., Ren, Y., Yin, Z. Y., Lin, Z., and Zheng, D.: Spatial and temporal variation patterns of reference evapotranspiration across the Qinghai-Tibetan Plateau during 1971-2004, J. Geophys. Res., 114, 1-14, doi: 10.1029/2009jd011753, 2009.

Zhang, S. J., Zhang, Y. S., Sui, D., Cai, F., Wu, J. W., Ji, R. P., Chen, P. S., and Lu, Q. W.: Changes in reference evapotranspiration and its causes in northeast China, Journal of natural Resources., 25, 1750-1761, doi: 1000 -3037( 2010) $10-1750-12,2010$.

Zhang, Y. L., Qin, B. Q., and Chen, W. M.: Analysis of 40 year records of solar radiation data in Shanghai, Nanjing and Hangzhou in Eastern China, Theor. Appl. Climatol., 78, doi: 10.1007/s00704-003-0030-7, 2004.

Zhang, Z. B., Yang, Y., Zhang, X. P., and Chen, Z. J.: Wind speed changes and its influencing factors in Southwestern China, Acta Ecologica Sinica., 34, 471-481, doi: 10.5846 /stxb201305141051, 2014. 
Hydrol. Earth Syst. Sci. Discuss., doi:10.5194/hess-2017-241, 2017

Manuscript under review for journal Hydrol. Earth Syst. Sci.

Discussion started: 2 May 2017

(c) Author(s) 2017. CC-BY 3.0 License.

(c) (1)

Zhang, D., Liu, X., and Hong, H.: Assessing the effect of climate change on reference evapotranspiration in China, Stoch. Environ. Res. Risk Assess., 27, 1871-1881, doi: 10.1007/s00477-013-0723-0, 2013.

Zhou, Q., Bing, J. J., and Zhang, J. Y.: Variation of air temperature and thermal resources in the northern and southern regions of the Qinling Mountains from 1951 to 2009, Acta Geographica Sinica., 66, 1211-1218, doi: 10.5846 / stxb201401190145, 2011.

590 Zhou, D., Zhao, S., Liu, S., Zhang, L., and Zhu, C.: Surface urban heat island in China's 32 major cities: Spatial patterns and drivers, Remote Sens. Environ., 152, 51-61, doi: 10.1016/j.rse.2014.05.017, 2014. 
Hydrol. Earth Syst. Sci. Discuss., doi:10.5194/hess-2017-241, 2017

Manuscript under review for journal Hydrol. Earth Syst. Sci.

Discussion started: 2 May 2017

(c) Author(s) 2017. CC-BY 3.0 License.

Table 1. Trends of key meteorological variables in Qinhuai River Basin during 1961-1987 and 1988-2012

\begin{tabular}{|c|c|c|c|c|c|c|c|}
\hline Periods & Variables & Spring & Summer & Autumn & Winter & $\begin{array}{l}\text { Growing } \\
\text { season }\end{array}$ & Annual \\
\hline \multirow[t]{8}{*}{$1961-1987$} & $\operatorname{Rs}\left(M J \cdot m^{-2} \cdot d^{-1}\right)$ & - & $-0.061 *$ & - & - & - & $-0.027^{*}$ \\
\hline & $\mathrm{WS}\left(\mathrm{m} \cdot \mathrm{s}^{-1}\right)$ & $0.031^{* * *}$ & $-0.014^{*}$ & $0.032^{* * *}$ & $0.034^{* * * *}$ & $-0.025^{* * *}$ & $0.027^{* * *}$ \\
\hline & $\mathrm{RH}(\%)$ & - & $0.11^{*}$ & - & - & - & - \\
\hline & $\mathrm{AH}\left(\mathrm{g} \mathrm{m}^{3}\right)$ & - & - & - & - & - & - \\
\hline & VPD (kpa) & - & $-0.005^{* *}$ & - & - & - & - \\
\hline & $\mathrm{T}_{\text {mean }}\left({ }^{\circ} \mathrm{C}\right)$ & - & - & - & $-0.043^{*}$ & - & - \\
\hline & $\mathrm{T}_{\max }\left({ }^{\circ} \mathrm{C}\right)$ & - & $-0.054^{* *}$ & - & - & $-0.026^{+}$ & $-0.029^{*}$ \\
\hline & $\mathrm{T}_{\min }\left({ }^{\circ} \mathrm{C}\right)$ & - & $-0.029^{*}$ & - & - & - & - \\
\hline \multirow[t]{8}{*}{$1988-2012$} & $\mathrm{Rs}\left(\mathrm{MJ} \mathrm{m}^{-2} \mathrm{~d}^{-1}\right)$ & $0.048^{+}$ & $-0.073^{+}$ & $-0.051^{*}$ & - & $-0.049^{+}$ & - \\
\hline & $\mathrm{WS}\left(\mathrm{m} \mathrm{s}^{-1}\right)$ & - & - & - & - & - & - \\
\hline & $\mathrm{RH}(\%)$ & $-0.52^{* * *}$ & $-0.31^{* * * *}$ & $-0.20^{*}$ & $-0.28^{* * *}$ & $-0.33^{* * *}$ & $-0.38^{* * *}$ \\
\hline & $\mathrm{AH}\left(\mathrm{g} \mathrm{m}^{3}\right)$ & - & $-0.046^{*}$ & - & $-0.024^{+}$ & $-0.030^{+}$ & - \\
\hline & VPD (kpa) & $0.014^{* * *}$ & $0.014^{* * *}$ & $0.007^{* * * *}$ & $0.003^{*}$ & $0.013^{* * *}$ & $0.010^{* * *}$ \\
\hline & $\mathrm{T}_{\text {mean }}\left({ }^{\circ} \mathrm{C}\right)$ & $0.079^{* *}$ & $0.038^{+}$ & $0.058^{* *}$ & - & $0.045^{* *}$ & $0.039^{*}$ \\
\hline & $\mathrm{T}_{\max }\left({ }^{\circ} \mathrm{C}\right)$ & $0.114^{* *}$ & $0.037^{+}$ & - & - & $0.048^{* *}$ & $0.038^{+}$ \\
\hline & $\mathrm{T}_{\min }\left({ }^{\circ} \mathrm{C}\right)$ & $0.056^{+}$ & $0.045^{*}$ & $0.084^{* *}$ & - & $0.055^{* * *}$ & $0.041^{*}$ \\
\hline
\end{tabular}

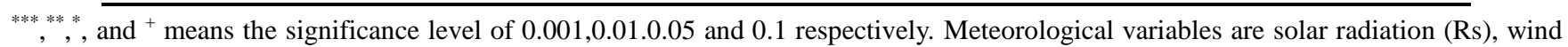
speed (WS), relative humidity $(\mathrm{RH})$, absolute humidity $(\mathrm{AH})$, vapor pressure deficit (VPD), mean temperature ( $\mathrm{T}_{\text {mean }}$ ), maximum temperature $\left(\mathrm{T}_{\max }\right)$, and minimum temperature $\left(\mathrm{T}_{\min }\right)$ 
Hydrol. Earth Syst. Sci. Discuss., doi:10.5194/hess-2017-241, 2017

Manuscript under review for journal Hydrol. Earth Syst. Sci.

Discussion started: 2 May 2017

(c) Author(s) 2017. CC-BY 3.0 License.

Table 2. Mean seasonal and annual ETo estimated by $\mathrm{P}-\mathrm{M}$ model; trends of seasonal and annual ETo obtained through Mann-Kendall test during 1961-1987 and 1988-2012

\begin{tabular}{|c|c|c|c|c|c|c|}
\hline \multirow{2}{*}{ Season } & \multicolumn{3}{|c|}{$1961-1987$} & \multicolumn{3}{|c|}{ 1988-2012 } \\
\hline & ETo (mm) & Trend & $\beta\left(\mathrm{mm} \mathrm{yr}^{-1}\right)$ & ETo (mm) & Trend & $\beta\left(\mathrm{mm} \mathrm{yr}^{-1}\right)$ \\
\hline Spring & 266 & $\downarrow$ & -0.04 & 280 & $\uparrow^{* *}$ & 2.55 \\
\hline Summer & 404 & $\downarrow^{* *}$ & -2.05 & 391 & $\uparrow$ & 0.16 \\
\hline Autumn & 206 & $\downarrow$ & -0.57 & 211 & $\uparrow^{+}$ & 0.38 \\
\hline Winter & 102 & $\downarrow^{+}$ & -0.37 & 100 & $\uparrow^{*}$ & 0.56 \\
\hline Growing season & 685 & $\downarrow^{*}$ & -2.53 & 679 & $\uparrow$ & 1.09 \\
\hline Annual & 980 & $\downarrow^{* *}$ & -3.82 & 982 & $\uparrow^{* *}$ & 3.16 \\
\hline
\end{tabular}

${ }^{* * * * * * *+},+$ means the significance level of $0.001,0.01 .0 .05$ and $0.1 . \beta$ is the estimated magnitude of slopes of ETo trends. $\beta>0$ represents an increasing trend $(\uparrow) ; \beta<0$ represents a decreasing trend $(\downarrow)$. 
Hydrol. Earth Syst. Sci. Discuss., doi:10.5194/hess-2017-241, 2017

Manuscript under review for journal Hydrol. Earth Syst. Sci.

Discussion started: 2 May 2017

(c) Author(s) 2017. CC-BY 3.0 License.

655 Table 3. The trends of ETo and dominant meteorological variables in different basins of China

\begin{tabular}{|c|c|c|c|c|}
\hline Region & Periods & Trends of ETo & Dominant meteorological variables & References \\
\hline China & $1971-2008$ & $\begin{array}{l}\text { Decreased in } \\
1971-2008\end{array}$ & $\begin{array}{l}\text { Declining wind speed and decreasing } \\
\text { sunshine duration }\end{array}$ & Yin et al. (2010) \\
\hline China & 1960-2011 & $\begin{array}{l}\text { Increased in } \\
1993-2011\end{array}$ & $\begin{array}{l}\text { Before 1992: decrease in solar } \\
\text { radiation in humid region; decrease in } \\
\text { wind speed in arid and } \\
\text { semi-arid/semi-humid region } \\
\text { After 1992: rapidly increasing } \\
\text { temperature in all three regions }\end{array}$ & Zhang et al. (2013) \\
\hline $\begin{array}{l}\text { Yangtze River } \\
\text { Basin }\end{array}$ & $1960-2000$ & Decreased & $\begin{array}{l}\text { Decrease in net total radiation and } \\
\text { wind speed }\end{array}$ & Xu et al. (2006) \\
\hline $\begin{array}{l}\text { Yellow River } \\
\text { Basin }\end{array}$ & $1961-2006$ & $\begin{array}{l}\text { Increased in the } \\
\text { whole basin }\end{array}$ & $\begin{array}{l}\text { Increasing air temperature and } \\
\text { decreasing relative humidity }\end{array}$ & Liu et al. (2010) \\
\hline $\begin{array}{l}\text { Jing River } \\
\text { Basin }\end{array}$ & 1960-2005 & $\begin{array}{l}\text { Decreased in spring, } \\
\text { summer and winter; } \\
\text { Increased in autumn }\end{array}$ & $\begin{array}{l}\text { Spring, summer and winter: decrease } \\
\text { in wind speed; } \\
\text { Autumn: increase in maximum } \\
\text { temperature; }\end{array}$ & Xu et al. (2015) \\
\hline $\begin{array}{l}\text { Taohe River } \\
\text { Basin }\end{array}$ & $1981-2010$ & Increased & $\begin{array}{l}\text { Increasing air temperature and net } \\
\text { total radiation }\end{array}$ & Yang et al. (2014) \\
\hline $\begin{array}{l}\text { Hai River } \\
\text { Basin }\end{array}$ & 1960-2012 & $\begin{array}{l}\text { Decreased in } \\
1960-1989 \\
\text { Increased in } \\
1990-2012\end{array}$ & $\begin{array}{l}\text { Before 1989: decrease in solar } \\
\text { radiation } \\
\text { After 1989: global warming }\end{array}$ & Zhao et al. (2015) \\
\hline $\begin{array}{l}\text { Qinhuai River } \\
\text { Bain }\end{array}$ & $1961-2012$ & $\begin{array}{l}\text { Decreased in } \\
\text { 1961-1987; } \\
\text { Increased in } \\
\text { 1988-2012 }\end{array}$ & $\begin{array}{l}\text { Before 1987: decrease in wind speed, } \\
\text { solar radiation and VPD; } \\
\text { After 1987: rapidly increasing VPD } \\
\text { and increasing } \mathrm{T}_{\max }\end{array}$ & This study \\
\hline
\end{tabular}


Hydrol. Earth Syst. Sci. Discuss., doi:10.5194/hess-2017-241, 2017

Manuscript under review for journal Hydrol. Earth Syst. Sci.

Discussion started: 2 May 2017

(c) Author(s) 2017. CC-BY 3.0 License.
Hydrology and

(c) (1)

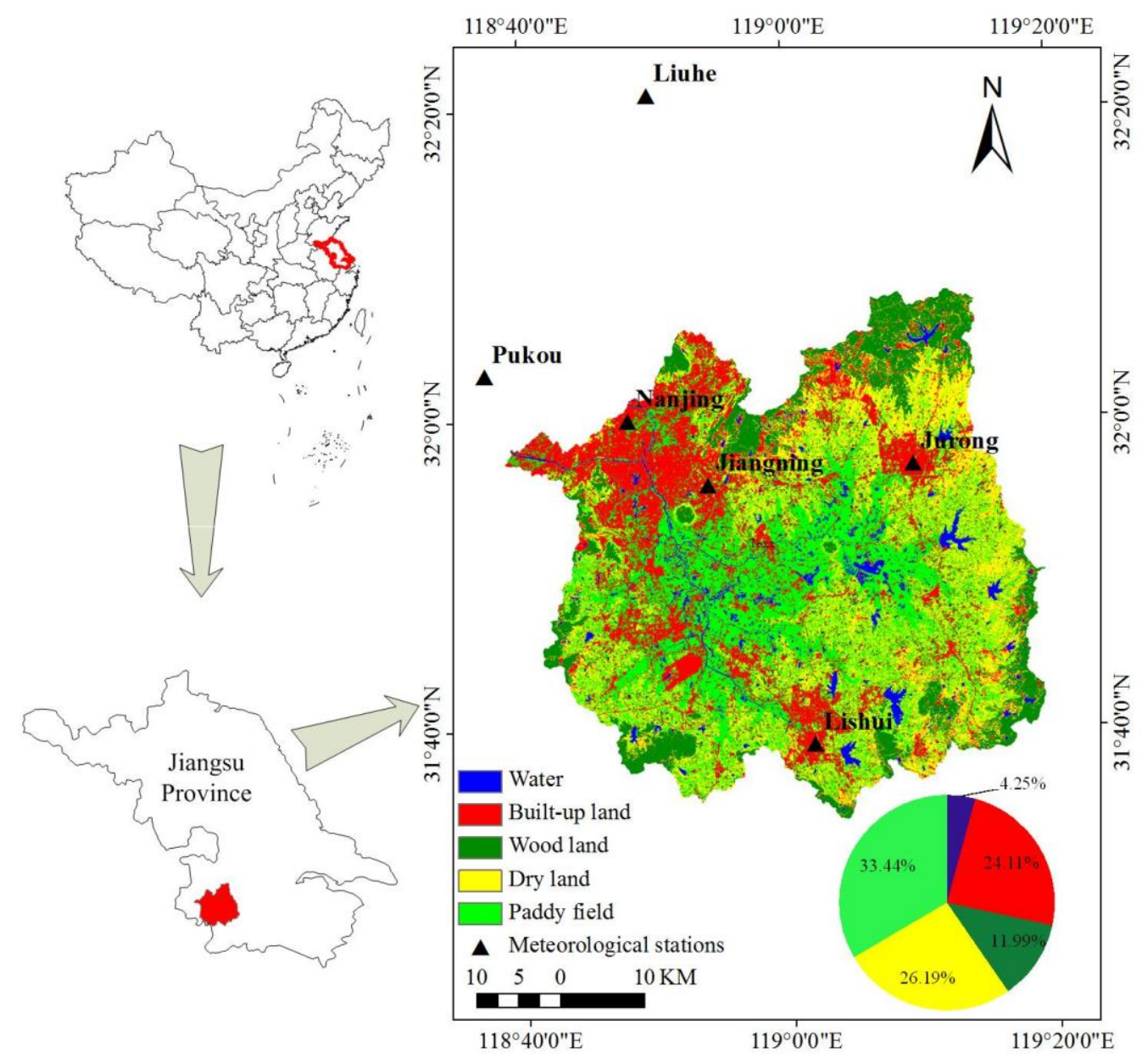

665 Fig. 1. Watershed location, land use and land cover (2013), and weather stations around the Qinhuai River Basin. The insert pie chart indicates the proportion of five land use area to total area. 
Hydrol. Earth Syst. Sci. Discuss., doi:10.5194/hess-2017-241, 2017

Manuscript under review for journal Hydrol. Earth Syst. Sci.

Discussion started: 2 May 2017

(c) Author(s) 2017. CC-BY 3.0 License.

(c) (1)
Hydrology and o

Earth System

Sciences

Discussions (a)

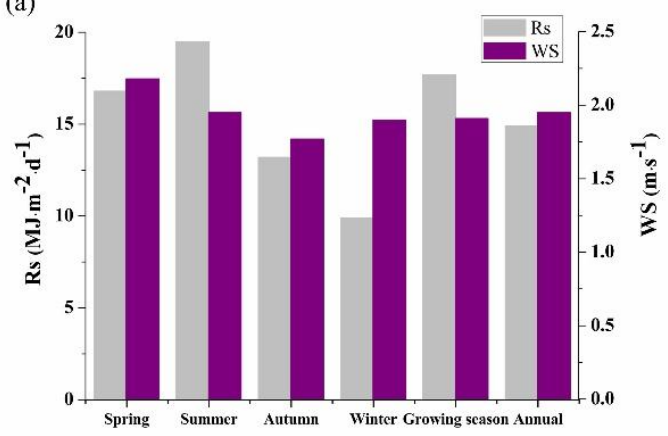

(c)

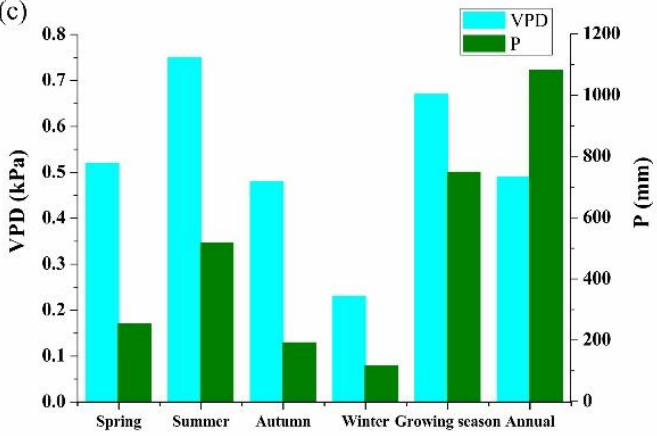

(b)

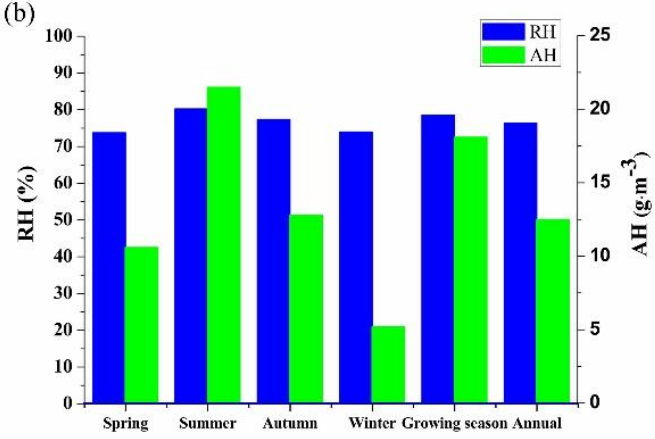

(d)

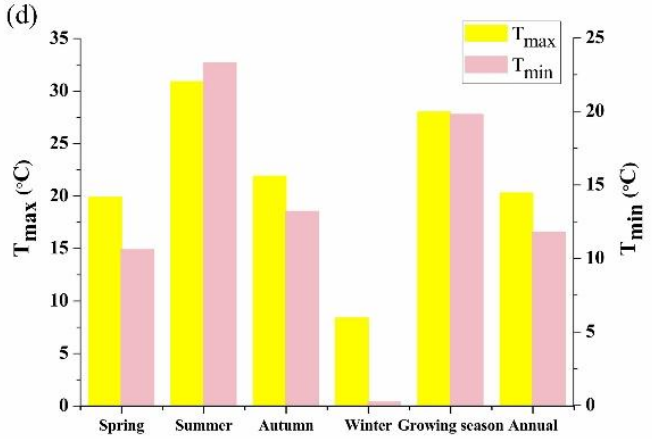

Fig. 2. Basic meteorological information in Qinhuai River basin during 1961-2012: (a) Solar radiation $\left(\mathrm{R}_{\mathrm{s}}\right)$ and Wind speed (WS); (b) Relative humidity (RH) and Absolute humidity (AH); (c) Vapor pressure deficit (VPD) and Precipitation ( $\mathrm{p})$; and $(\mathbf{d})$ Maximum temperature $\left(\mathrm{T}_{\max }\right)$ and Minimum temperature $\left(\mathrm{T}_{\min }\right)$. 
Hydrol. Earth Syst. Sci. Discuss., doi:10.5194/hess-2017-241, 2017

Manuscript under review for journal Hydrol. Earth Syst. Sci.

Discussion started: 2 May 2017
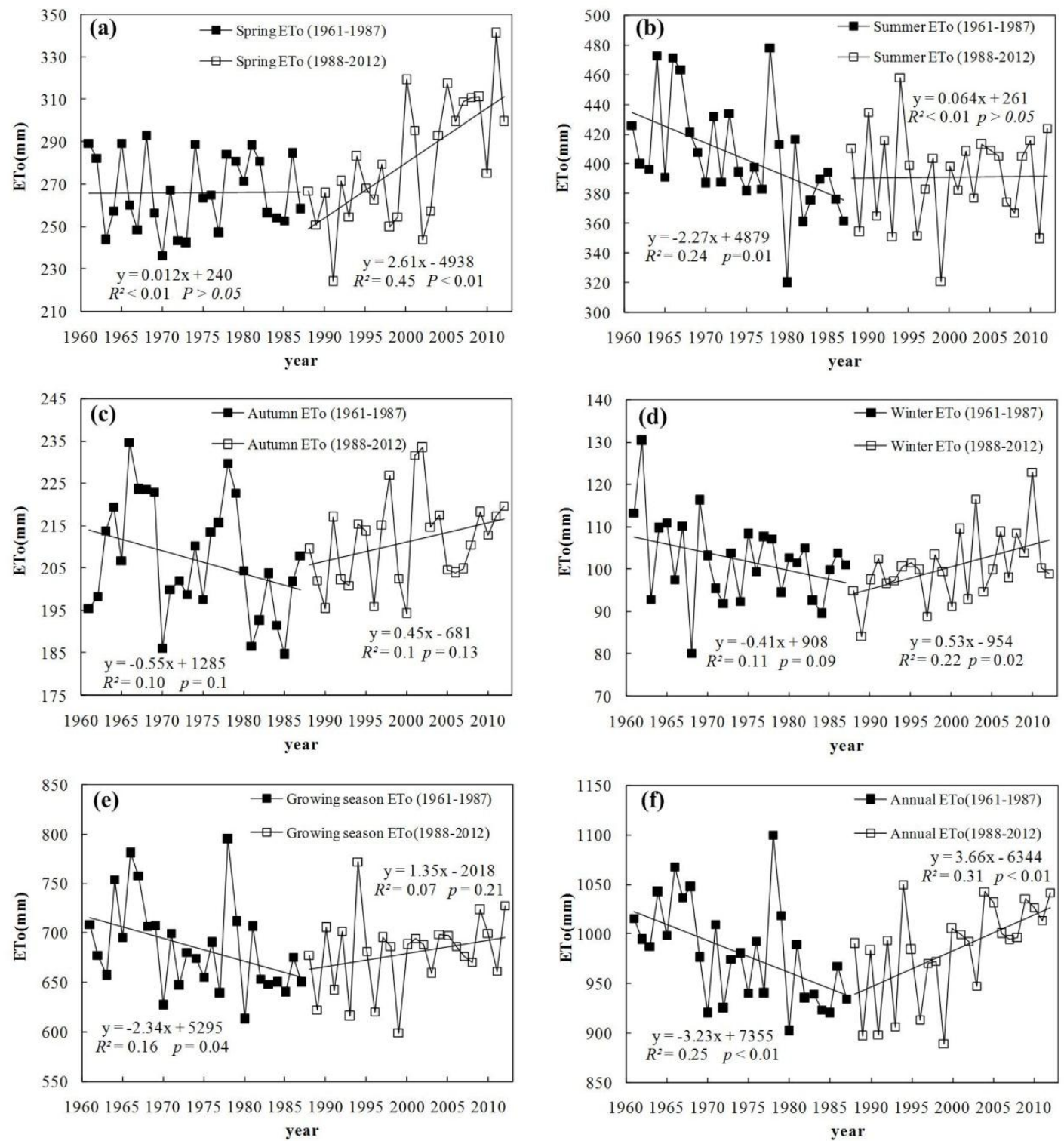

Fig. 3. Linear fitted trends of (a) spring; (b) summer; (c) autumn; (d) winter; (e) growing season; and (f) annual ETo during 1961-1987 and 1988-2012. 
Hydrol. Earth Syst. Sci. Discuss., doi:10.5194/hess-2017-241, 2017

Manuscript under review for journal Hydrol. Earth Syst. Sci.

Discussion started: 2 May 2017
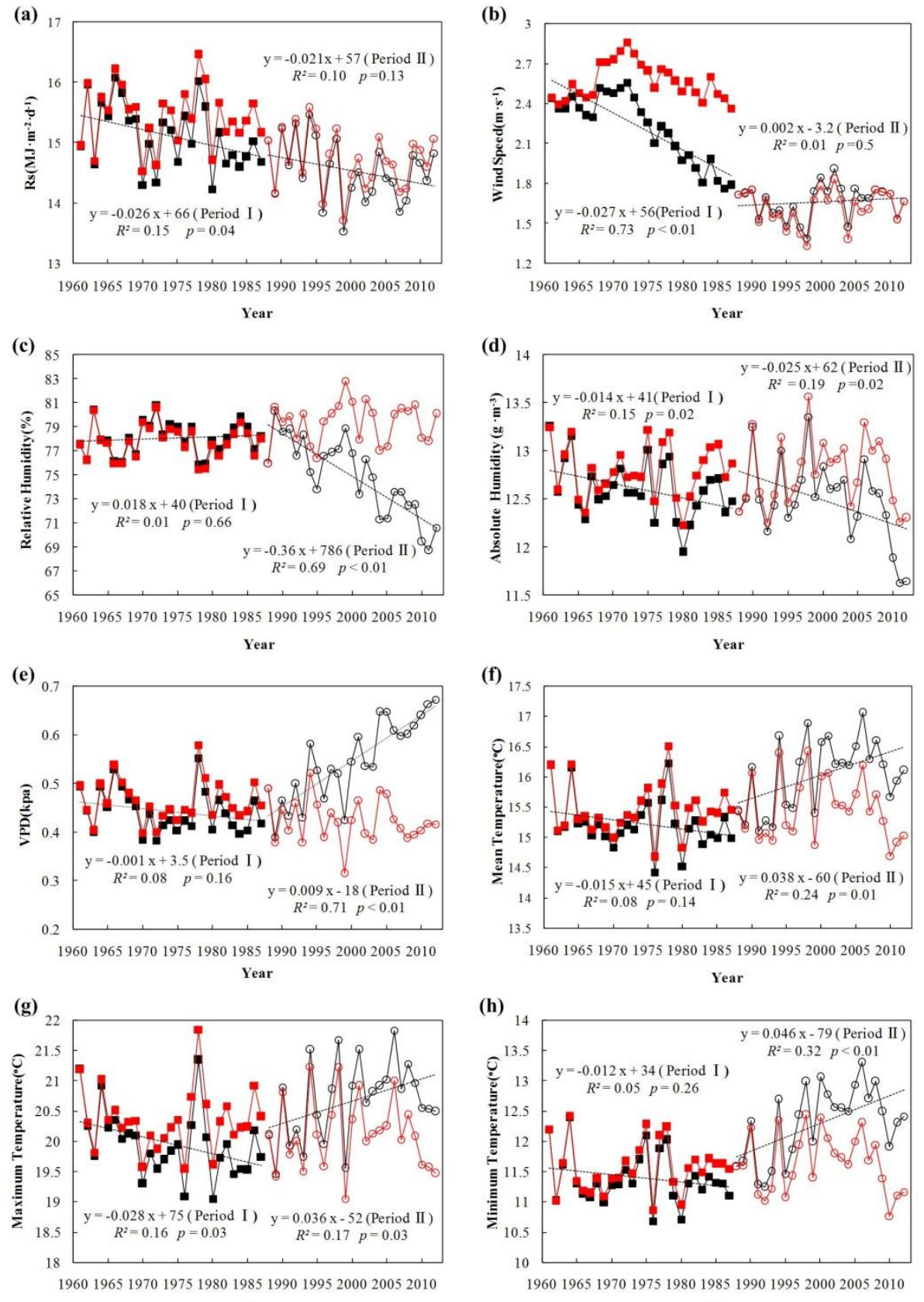

$$
\text { Year }
$$

Year

-Original (1961-1987) -Detrended(1961-1987) $\quad \ominus$ Original (1988-2012) $\quad \ominus$ Detrended(1988-2012)

Fig. 4.The annual original and detrended meteorological variables (a) Solar radiation $\left(\mathrm{R}_{\mathrm{s}}\right)$; (b) Wind speed (WS); (c)Relative humidity (RH); (d) Absolute humidity (AH); (e) Vapor pressure deficit (VPD); (f) Mean temperature $\left(\mathrm{T}_{\text {mean }}\right) ;(\mathbf{g})$ Maximum temperature $\left(\mathrm{T}_{\max }\right)$; and $(\mathbf{h})$ Minimum temperature $\left(\mathrm{T}_{\min }\right)$ for Qinhuai River basin by using detrending method (Period I represents 1961-1987 and Period II represents 1988-2012). 
Hydrol. Earth Syst. Sci. Discuss., doi:10.5194/hess-2017-241, 2017

Manuscript under review for journal Hydrol. Earth Syst. Sci.

Discussion started: 2 May 2017

(c) Author(s) 2017. CC-BY 3.0 License.



(c)

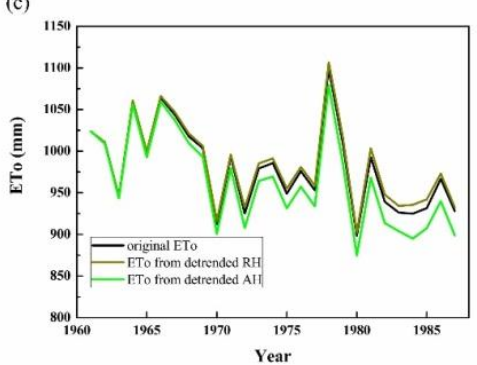

(e)

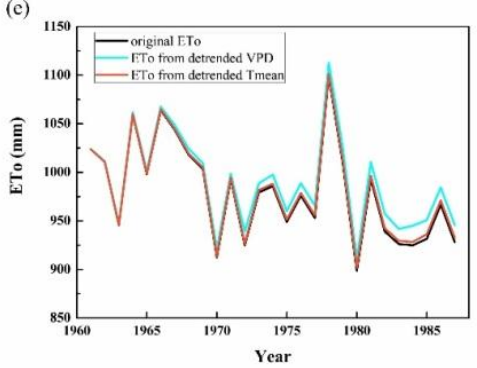

(g)

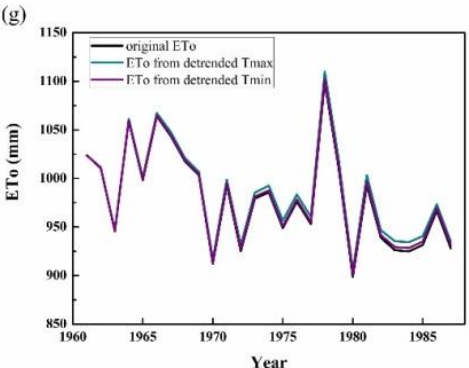

(b)

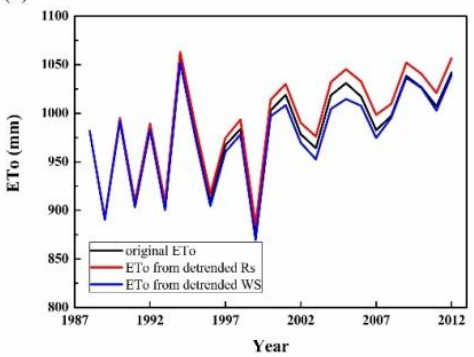

(d)

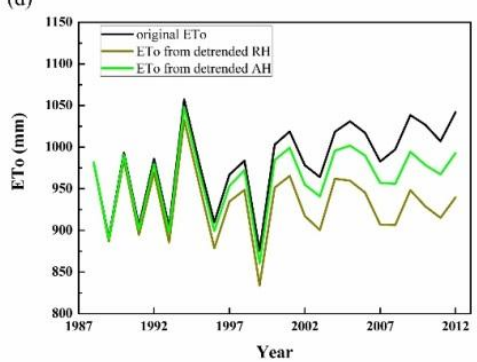

(f)

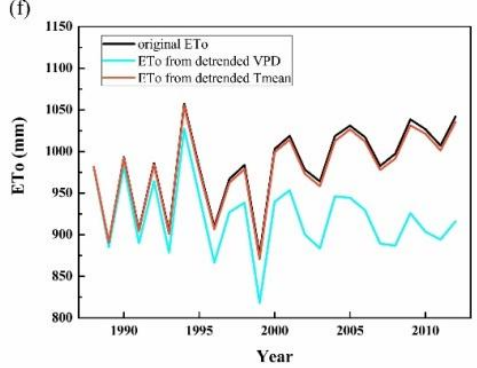

(h)

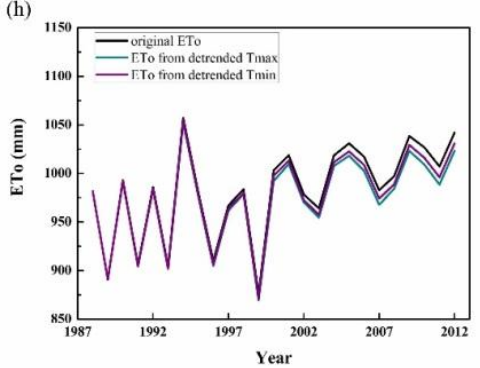

Fig. 5. The original and recalculated annual ETo for Qinhuai River basin with detrended meteorological variables during 1960-1987 (a) Solar radiation $\left(\mathrm{R}_{\mathrm{s}}\right.$ ) and Wind speed (WS); (c) Relative humidity (RH) and Absolute humidity (AH); (e) Vapor pressure deficit (VPD) and Mean temperature $\left(\mathrm{T}_{\text {mean }}\right)$; $(\mathrm{g})$ Maximum temperature $\left(\mathrm{T}_{\max }\right)$ and Minimum temperature $\left(\mathrm{T}_{\min }\right)$; and 1988-2012 (b) Solar radiation $\left(\mathrm{R}_{\mathrm{s}}\right.$ ) and Wind speed (WS); (d) Relative humidity (RH) and Absolute humidity (AH); (f) Vapor pressure deficit (VPD) and Mean temperature ( $\left.\mathrm{T}_{\text {mean }}\right)$; and (h) Maximum temperature $\left(\mathrm{T}_{\max }\right)$ and Minimum temperature $\left(\mathrm{T}_{\min }\right)$. 
Hydrol. Earth Syst. Sci. Discuss., doi:10.5194/hess-2017-241, 2017

Manuscript under review for journal Hydrol. Earth Syst. Sci.

Discussion started: 2 May 2017
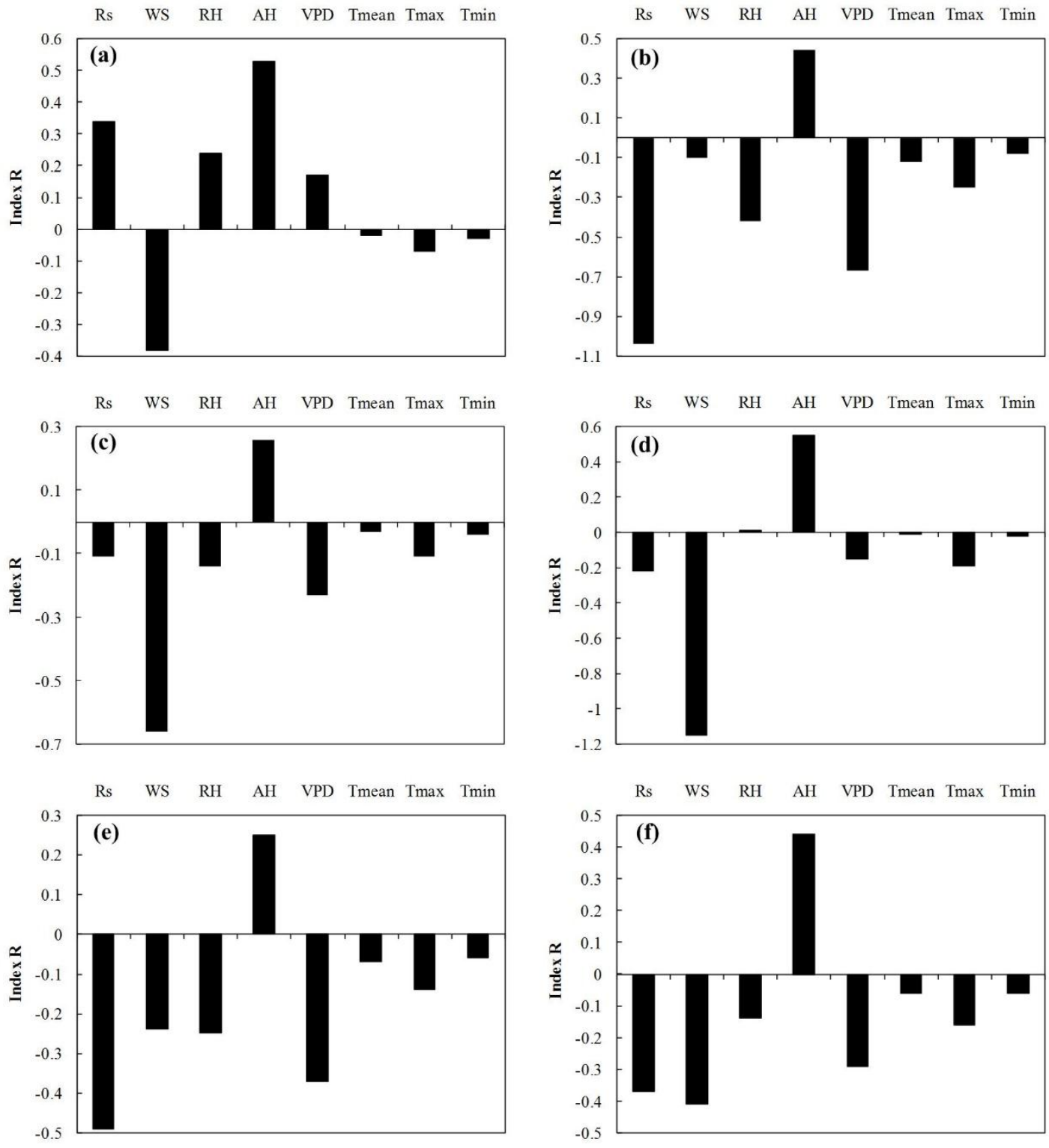

Fig. 6. Comparisons of indicator $\mathrm{R}$ for identifying the contributions of trends in meteorological variables to trends in ETo in (a) spring; (b) summer; (c) autumn; (d) winter; (e) growing season; and (f) annual during 1961-1987. Positive $R$ values indicate positive effects and negative values indicate negative effects; the greater of the absolute $R$ values indicate greater contributions to changes in ETo. 
Hydrol. Earth Syst. Sci. Discuss., doi:10.5194/hess-2017-241, 2017

Manuscript under review for journal Hydrol. Earth Syst. Sci.

Discussion started: 2 May 2017
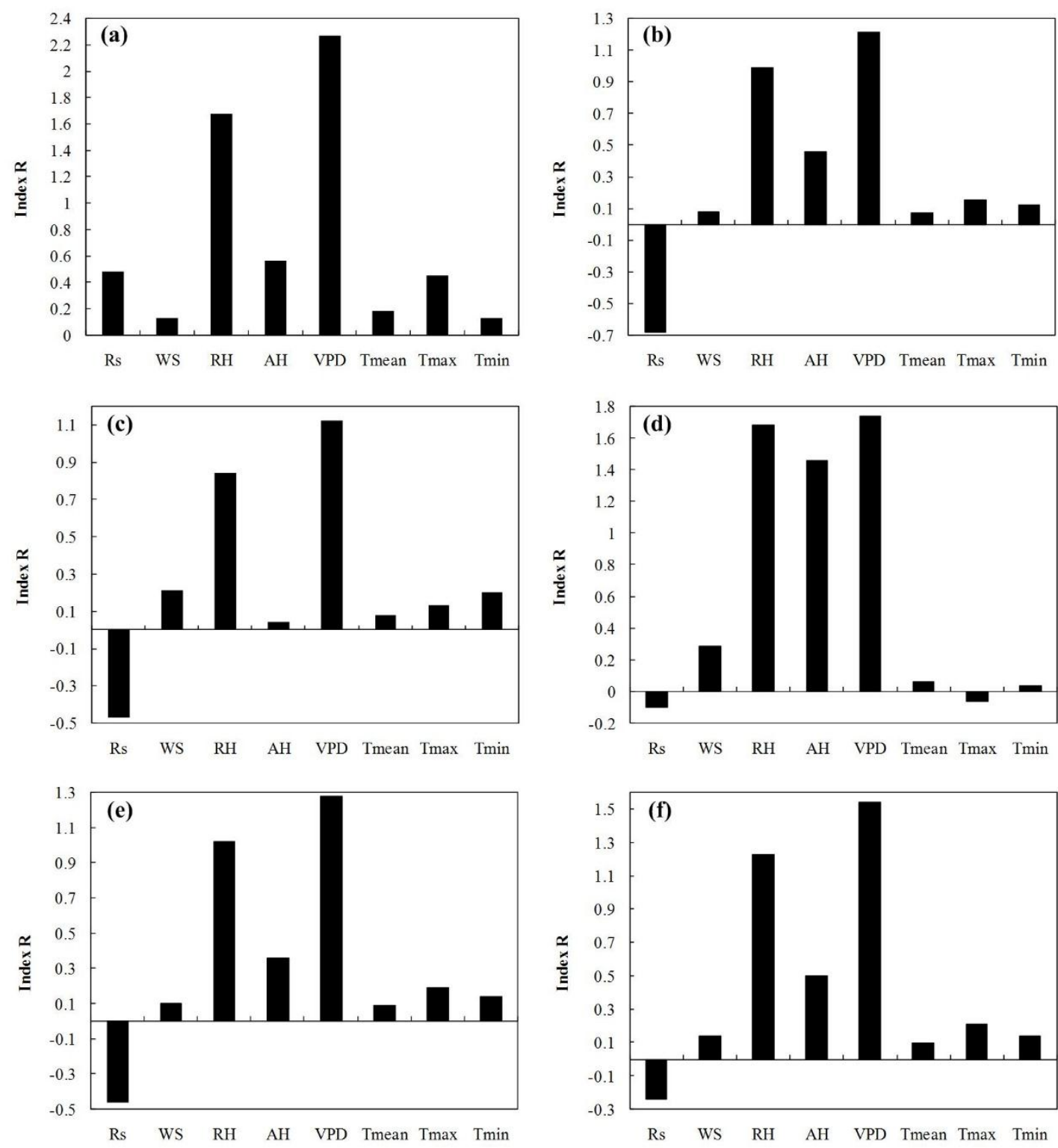

Fig. 7. Comparisons of evaluating indicator $\mathrm{R}$ for identifying the contributions of trends in meteorological variables to trends in ETo in (a) spring; (b) summer; (c) autumn; (d) winter; (e) growing season; and (f) annual during 1988-2012. Positive $\mathrm{R}$ values indicate positive effects and negative values indicate negative effects; the greater of the absolute $\mathrm{R}$ values indicate greater contributions to changes in ETo. 